\title{
1 \\ Mechanistic Aspects of Metal-Catalyzed C,C- and C,X-Bond-Forming Reactions
}

\author{
Antonio M. Echavarren and Diego J. Cárdenas
}

1.1

Mechanisms of Cross-Coupling Reactions

Cross-coupling reactions, such as the Stille reaction of organostannanes [1-3] and the Suzuki (or Suzuki-Miyaura) cross-coupling of organoboron compounds [4] have settled amongst the more general and selective palladium-catalyzed cross-coupling reactions [5] (Scheme 1-1). These reactions are closely related to other cross-couplings based on transmetallations of a variety of hard or soft organometallic nucleophiles [6] such as the Hiyama [7, 8], Sonogashira [9], Kumada (or Kumada-Corriu), and other related couplings [10-12].

Coupling reactions are somewhat related to the Heck alkenylation of organic electrophiles $[13,14]$, which is often referred to in the literature as a coupling process. However, although the first steps in both processes are identical, in the Heck reaction there is no transmetallation step. In the alkenylation reaction, the C-C bond is formed by an insertion process, which is followed by a $\beta$-hydride elimination to form the substituted alkene product. Cross-coupling (transmetallationbased) processes are a family of closely related catalytic processes that share most mechanistic aspects, although some differences exist on the activation of the organometallic nucleophile. So far, most of the detailed mechanistic studies have cen-

Stille

$$
\mathrm{R}-\mathrm{X}+\mathrm{R}^{\prime}-\mathrm{Sn}-\stackrel{[\mathrm{Pd}(0)]}{\longrightarrow} \mathrm{R}-\mathrm{R}^{\prime}+\stackrel{-}{\longrightarrow} \mathrm{Sn-X}
$$

Suzuki

$$
\mathrm{R}-\mathrm{X}+\mathrm{R}^{\prime}-\mathrm{B}^{\prime} \quad \underset{\mathrm{R}^{\prime \prime} \mathrm{O}^{-}}{\stackrel{[\mathrm{Pd}(0)]}{\longrightarrow}} \mathrm{R}-\mathrm{R}^{\prime}+\mathrm{B}-\mathrm{OR}
$$

Hiyama

$$
\mathrm{R}-\mathrm{X}+\mathrm{R}^{\prime}-\mathrm{Si}-\quad \stackrel{[\mathrm{Pd}(0)]}{\mathrm{F}^{-}} \mathrm{R}-\mathrm{R}^{\prime}+\underset{\mathrm{Si}-\mathrm{X}}{ } \begin{aligned}
& \begin{array}{l}
\text { Scheme 1-1 Representative } \\
\text { palladium-catalyzed cross-cou- } \\
\text { pling reactions. }
\end{array}
\end{aligned}
$$

Metal-Catalyzed Cross-Coupling Reactions, 2nd Edition. Edited by Armin de Meijere, François Diederich Copyright (C) 2004 WILEY-VCH Verlag GmbH \& Co. KGaA, Weinheim ISBN 3-527-30518-1 
tered on the coupling of organostannanes with organic electrophiles catalyzed by palladium (Stille reaction) $[1,2,15]$. However, the conclusions that arise from studies conducted on this reaction probably pertain to other cross-couplings. Although nickel, copper - and occasionally also platinum - have also been used as catalysts for cross-coupling processes, the vast majority of mechanistic studies concern palladium chemistry.

The mechanisms of palladium-catalyzed formations of C-X $(X=N, O, S)$ from organic electrophiles bonds are roughly related to cross-coupling processes. However, recent mechanistic investigations point to differences with regards to some of the details in the catalytic cycle.

\subsection{1}

\section{The Earlier Mechanistic Proposal: The Stille Reaction}

The extensive synthetic and mechanistic studies carried out by Stille since 1978 $[1,2,15,16]$ have allowed this reaction to be established as a mature synthetic method for organic synthesis [17]. The original mechanistic proposal for the Stille reaction, summarized in the influential review of 1986 [1] is shown in Scheme 1-2. In the generalized mechanism, a $\left[\mathrm{PdL}_{2}\right]\left(\mathrm{L}=\mathrm{PPh}_{3}\right)$ complex was assumed to be the active catalytic species, which reacts with the organic electrophile R-X to form complex 1 . Complex 1 was the only observable species in the catalytic cycle, even in the presence of excess organostannane, which demonstrated that the slow step is the transmetallation reaction with the organostannane. This transmetallation was believed to lead to the formation of complex 2. A trans-to-cis isomerization to give 3 was then required for the reductive elimination to yield the organic product R-R'.

This mechanistic interpretation of the Stille reaction has been the base for the formulation of the mechanisms of other cross-coupling reactions. Model studies carried out by Stang on the coupling of alkynes with vinyl triflates with $\left[\mathrm{Pt}\left(\mathrm{PPh}_{3}\right)_{4}\right]$ were in overall agreement with that proposal [18], although involvement of cationic complexes in the transmetallation step was strongly suggested by this

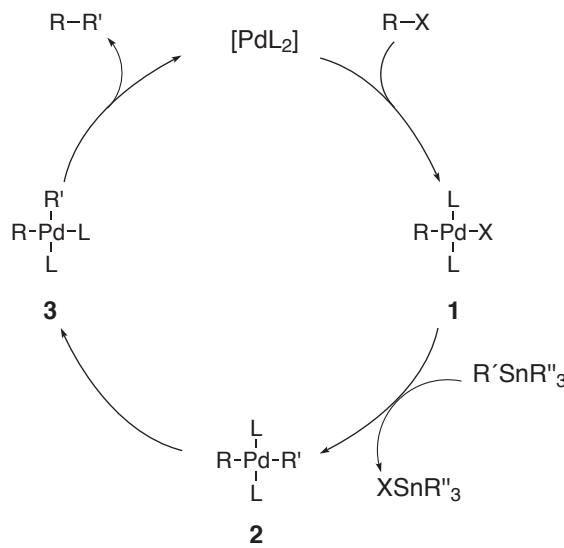

Scheme 1-2 The original proposal for the mechanism of the Stille reaction. 
work. Farina [19] and Brown [20] also found that the intermediates formed upon oxidative addition of organic triflates to $\operatorname{Pd}(0)$ are cationic complexes such as $\left[\mathrm{PdR}^{1}(\mathrm{~S}) \mathrm{L}_{2}\right]^{+}$and $\left[\mathrm{PdR}^{1} \mathrm{~L}_{3}\right]^{+}$.

Although these studies shed some light on the transmetallation step, this transformation has remained somewhat mechanistically obscure. Thus, for example, either inversion [21] or retention [22] of the configuration of alkyl stannanes has been found. In addition, theoretical studies and experimental results were in contradiction with several aspects of the mechanistic model of Scheme 1-2. In effect, intermediates of the type trans-[ $\left.\mathrm{PdR}^{1} \mathrm{R}^{2} \mathrm{~L}_{2}\right]$ (2) might be expected to be quite longlived, as trans-to-cis isomerizations in this type of complexes are not facile processes [23-25]. However, complexes 2 have never been detected under catalytic conditions [26].

\section{1 .2}

\section{The Oxidative Addition}

The oxidative addition of organic electrophiles (halides, sulfonates, and related activated compounds) to $\mathrm{Pd}(0)$ is the first step in cross-coupling and Heck reactions. Many studies have been conducted on the mechanisms of the oxidative addition reactions of aryl and alkenyl halides and triflates $\left(\mathrm{C}\left(\mathrm{sp}^{2}\right)-\mathrm{X}\right.$ electrophiles) [27], the most common organic electrophiles in the cross-coupling reactions.

The oxidative addition of $\mathrm{C}\left(\mathrm{sp}^{3}\right)$-X electrophiles to $\mathrm{Pd}(0)$ complexes $\mathrm{PdL}_{4}(\mathrm{~L}=$ phosphine) takes place usually by associative bimolecular process $\left(\mathrm{S}_{\mathrm{N}} 2\right.$ reaction) [27]. The anion then adds to the metal to give the product. However, the reaction of allylic electrophiles is more complex, since, in addition, $\mathrm{S}_{\mathrm{N}} 2^{\prime}$ substitutions are conceivable pathways. The coupling of trans allylic chloride 4 with $\mathrm{PhSnBu}_{3}$ proceeds with overall retention of configuration when the reaction was performed in benzene with a $\mathrm{Pd}(0)$ complex made in situ from $\left[\mathrm{Pd}\left(\eta^{3}-\mathrm{C}_{3} \mathrm{H}_{5}\right) \mathrm{Cl}\right]_{2}$ and maleic anhydride, while clean inversion was observed in polar, coordinating solvents [28] (Scheme 1-3). The observed stereochemistry is a consequence of the oxidative addition step. This reaction proceeds with complete or predominant retention in noncoordinating solvents as benzene, $\mathrm{CH}_{2} \mathrm{Cl}_{2}$, tetrahydrofuran (THF), or acetone $[28,29]$, which is in agreement with theoretical studies on the oxidative addition of $\mathrm{Pd}(0)$ to $\mathrm{CH}_{3} \mathrm{X}$ [30]. On the other hand, in coordinating solvents such as $\mathrm{MeCN}$ or dimethylsulfoxide (DMSO), complete or near-complete inversion was observed [28]. Syn-oxidative addition has also been observed on related substrates [31]. However, with $\left[\mathrm{Pd}\left(\mathrm{PPh}_{3}\right)_{4}\right]$, the usual inversion of configuration in the oxidative addition was observed [28, 32].

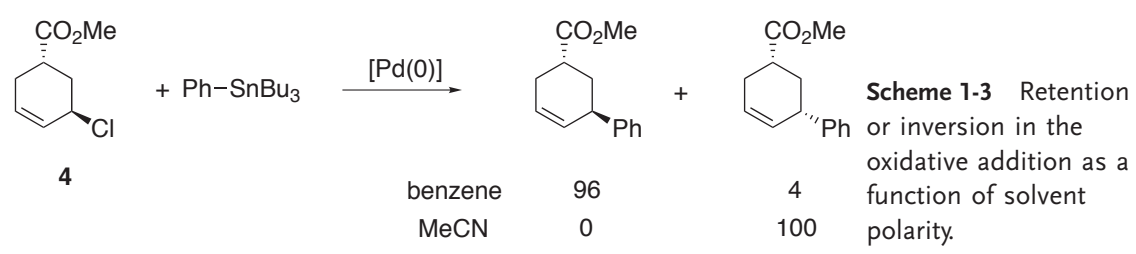


An earlier study on the mechanism of the oxidative addition of aryl iodides to $\left[\mathrm{PdL}_{2}\right]$ was consistent with an aromatic nucleophilic substitution [33]. Accordingly, electron-withdrawing substituents on aryl electrophiles led to rate acceleration [34, 35]. In general, increasing the bite angle of bidentate ligands leads to a decrease in the rate of the oxidative addition $[35,36]$. However, the opposite effect has also been observed [37], although in this case ligands of very different basicity were considered [38].

\subsubsection{Cis-Complexes in the Oxidative Addition}

The observed intermediates after the oxidative addition are trans-[PdRXL $\left.\mathrm{PL}_{2}\right] \mathrm{com}$ plexes (2, Scheme 1-2), which had led to the general proposal that these complexes are the primary products of the reaction. However, the oxidative addition (at least for the most common $\mathrm{C}\left(\mathrm{sp}^{2}\right)$-X electrophiles) proceeds by a concerted interaction of a reactive $\left[\mathrm{PdL}_{2}\right]$ or $[\mathrm{Pd}(\mathrm{L}-\mathrm{L})](\mathrm{L}-\mathrm{L}=$ diphosphine) species with $\mathrm{R}-\mathrm{X}$ via a three-center transition state that should necessarily lead to cis-[PdRXL $\left.\mathrm{PL}_{2}\right]$ complexes (Scheme 1-4). In the cis isomers a destabilizing interaction exists between mutually trans phosphorus donor and aryl ligands, which has been termed "transphobia" [39]. Therefore, in the case of complexes with monodentate phosphines, the initially formed cis-[ $\left.\mathrm{PdRXL}_{2}\right]$ (5) complexes undergo isomerization to form the more stable trans-[PdRXL $\mathrm{Pd}_{2}$ complexes [40]. Such isomerization is not possible for complexes 6 with cis-coordinating bidentate phosphines.

The isomerization process has been analyzed in detail by Casado and Espinet in the case of complex 7, formed by the oxidative addition of $\mathrm{C}_{6} \mathrm{Cl}_{2} \mathrm{~F}_{3} \mathrm{I}$ to $\left[\mathrm{Pd}\left(\mathrm{PPh}_{3}\right)_{4}\right]$ [41] (Scheme 1-5). The isomerization of cis-7 to trans-8 is a rather complex process that takes place by four major parallel pathways. Two of these pathways involve associative replacements of $\mathrm{PPh}_{3}$ by an iodide ligand of a second palladium com-
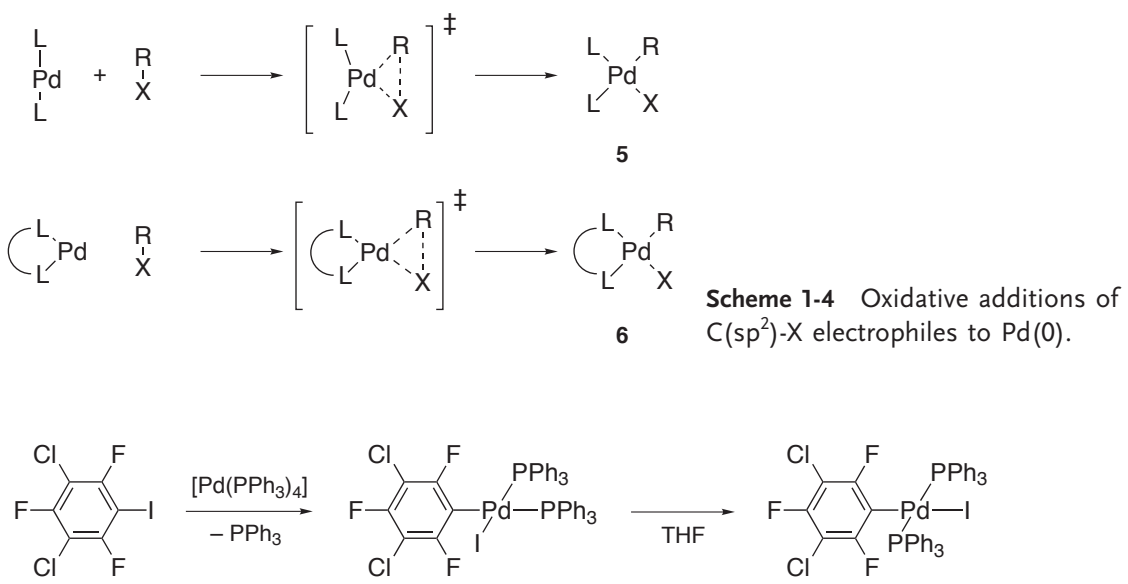

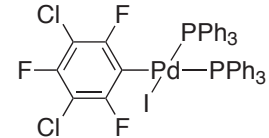<smiles>Fc1c(F)c(Cl)c(Cl)c(P(P)(I)(I)[Pb])c1F</smiles>

8

Scheme 1-5 Cis-to-trans isomerization of primary oxidative addition product. 
plex. Two additional routes involve two consecutive Berry pseudorotations on pentacoordinated species formed by coordination of the solvent (THF) [41].

\subsubsection{The Role of Alkene and Anionic Ligands}

Complex $\left[\mathrm{Pd}_{2}(\mathrm{dba})_{3} \cdot \mathrm{S}\right]$ (dba = dibenzylideneacetone, $\mathrm{S}=$ dba or solvent molecule) $[42,43]$ has been used as a source of $\operatorname{Pd}(0)$ in many palladium-catalyzed reactions [5]. Early work by Roundhill [44], and subsequent detailed studies by Amatore and Jutand [37, 45-47], established that the dba ligands are not completely substituted in the reactions of $\left[\mathrm{Pd}_{2}(\mathrm{dba})_{3} \cdot \mathrm{S}\right]$ with phosphines under mild conditions. With $\mathrm{PPh}_{3}$, mixtures of $\left[\mathrm{Pd}\left(\mathrm{PPh}_{3}\right)_{3}\right]$ in equilibrium with $\left[\mathrm{Pd}(\mathrm{dba})\left(\mathrm{PPh}_{3}\right)_{2}\right]$ are formed (Scheme 1-6) [44, 48]. As a result, starting from $\left[\mathrm{Pd}_{2}(\mathrm{dba})_{3}\right]$ and 2 equiv. of $\mathrm{PPh}_{3}$, the oxidative addition of PhI proceeds at an overall rate that is ca. 10 times less than that starting from $\left[\mathrm{Pd}\left(\mathrm{PPh}_{3}\right)_{4}\right]$. Similar equilibria were found for $\mathrm{L}=$ tri(2-furyl)phosphine (TFP) [49] and $\mathrm{L}=\mathrm{AsPh}_{3}$ [50].

Anionic ligands play an important role in oxidative addition reactions [51, 52]. Amatore and Jutand concluded that, in the presence of acetate, tricoordinated anionic species $\left[\mathrm{PdL}_{2}(\mathrm{OAc})\right]^{-}[53,54]$ (Scheme 1-7) are the effective complexes in oxidative addition [55], instead of the usually postulated neutral [ $\left.\mathrm{PdL}_{2}\right]$ complex.

In the presence of chloride, anionic complexes are also formed [56-59] (Scheme 1-8. In general, the following order of stabilization of the anionic $\operatorname{Pd}(0)$ species is observed: $\mathrm{I}^{-}>\mathrm{Br}^{-}>\mathrm{Cl}^{-}[59]$.
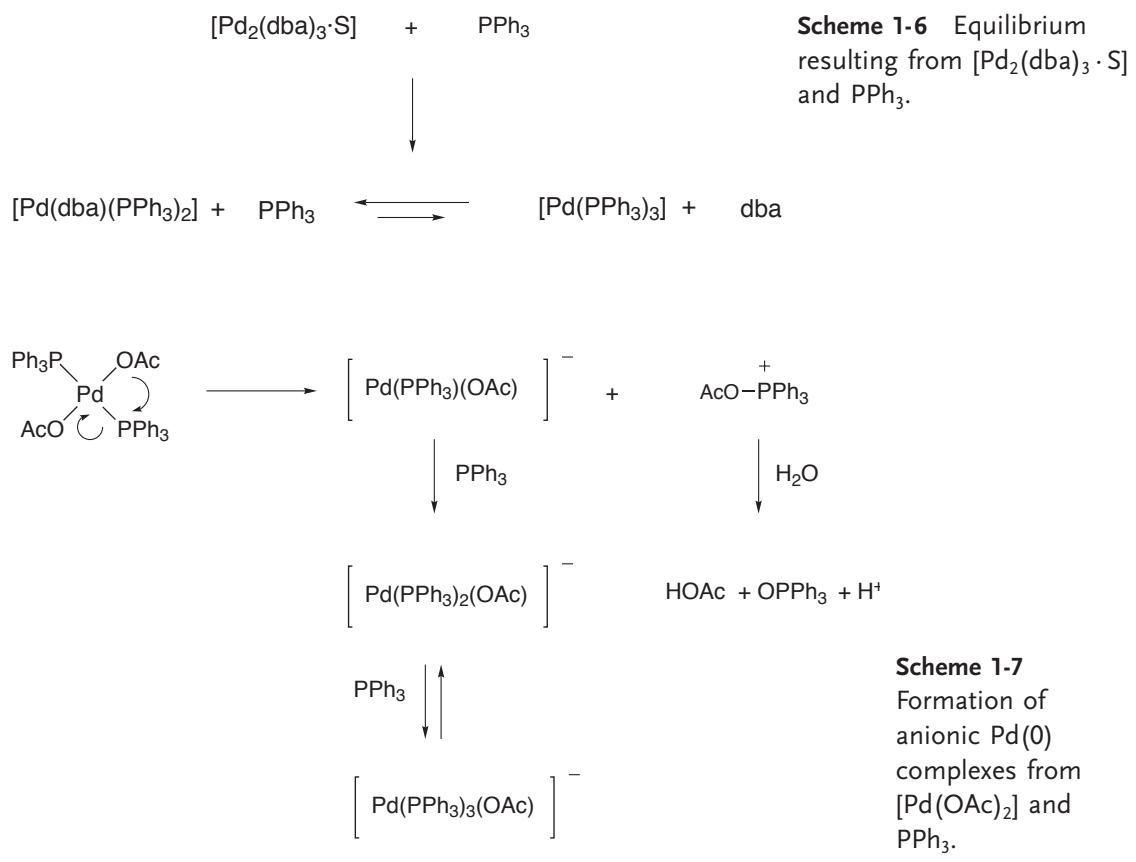
$\left[\mathrm{Pd}\left(\mathrm{PPh}_{3}\right)_{2} \mathrm{Cl}_{2}\right]$
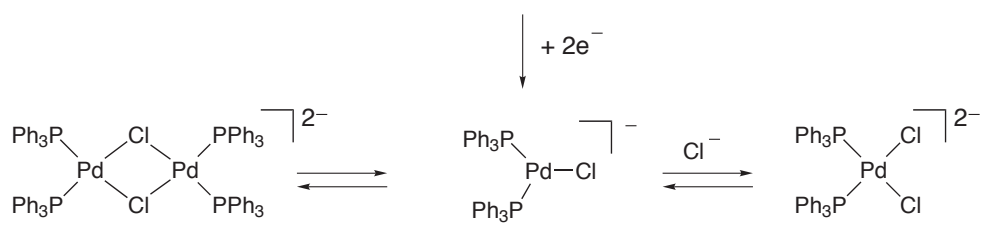

Scheme 1-8 Formation of anionic $\mathrm{Pd}(0)$ complexes from $\left[\mathrm{Pd}\left(\mathrm{PPh}_{3}\right)_{2} \mathrm{Cl}_{2}\right]$.

\subsubsection{Cross-Couplings in the Presence of Bulky Phosphines}

It may be risky to raise mechanistic conclusions on qualitative observations regarding rate accelerations upon changes on any reaction variable in complex catalytic processes such as cross-coupling reactions. Nevertheless, some interesting hints can be obtained from recent work aimed at developing new conditions for the coupling of the less reactive organic substrates such as aryl chlorides $[60,61]$ and alkyl electrophiles [62].

Aryl chlorides react more sluggishly in cross-coupling reactions than bromides, iodides, and triflates due to their reluctance to oxidatively add to $\mathrm{Pd}(0)$ [63]. Initially, the focus was on the development of sterically hindered, chelating ligands to activate these substrates. Thus, Milstein reported that $\left[\operatorname{Pd}(\operatorname{dippp})_{2}\right](\operatorname{dippp}=1,3$-bis(diisopropylphosphino)propane) was an efficient catalyst for the carbonylation, formylation, and Heck reactions of aryl chlorides [35, 64]. The groups of Hartwig and Buchwald also demonstrated the importance of a variety of sterically hindered, chelating phosphines such as $\mathbf{9}$ and $\mathbf{1 0}$ in palladium-catalyzed transformations (Scheme 1-9). In particular, the amination and etherification of aryl electrophiles [65], as well as the ketone and malonate arylation processes [66-68], benefit greatly from the use of this type of ligands. Another complex with a bulky chelating ligand (11) was developed by Guram as an efficient catalyst for general Suzuki reactions of a wide variety of arylboronic acids and aryl chlorides, bromides, and iodides [69].

Of note was the finding that relatively simple, monodentate phosphines also promote the coupling of the less reactive substrates under relatively mild conditions. This accelerating effect on the oxidative addition had been demonstrated in the context of the formation of ( $\eta^{3}$-allyl)palladium complexes [70]. Particularly useful for the activation of aryl chlorides are palladium complexes of the bulky phosphine $\mathrm{P}(t \mathrm{Bu})_{3}$ [71-74]. Bulkier phosphines such as (1-Ad) $\mathrm{P}(t \mathrm{Bu})_{2}(\mathrm{Ad}=$ adamantyl) have been used in the palladium-catalyzed arylation of malonates and cyanoesters [75]. The related bulky phosphine $\mathrm{P}(\mathrm{Bu})_{2}$-(o-biphenyl) (12) has been developed by Buch-

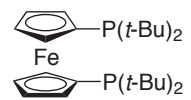

9

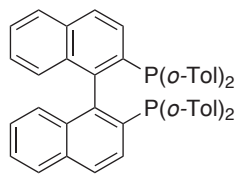

10

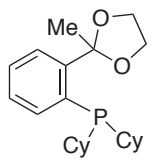

11

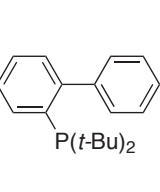

12
Scheme 1-9

Representative bulky ligands for the activation of the less reactive organic electrophiles. 
<smiles>[X]P(I)c1ccccc1</smiles>

13: $\mathrm{X}=\mathrm{O}, \mathrm{NH}$

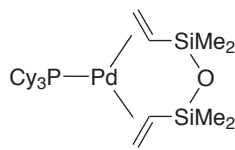

14

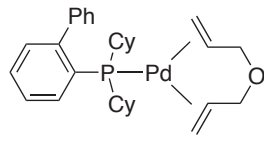

15
Scheme 1-10 Coordinatively unsaturated palladium complexes with bulky phosphines.

wald as a ligand for the palladium-catalyzed reaction of amines with aryl bromides, chlorides, and triflates [69a, 76-78] and in Suzuki coupling reactions [76a, 79].

Beller has shown that a series of coordinatively unsaturated [(1,6-diene)PdL] ( $\mathrm{L}=$ phosphine) complexes 13-15 (Scheme 1-10) catalyzes efficiently the Suzuki coupling of aryl chlorides with phenylboronic acid [80, 81]. Particularly effective as a catalyst was the complex bearing the phosphine ligand (o-biphenyl) $\mathrm{PCy}_{2}$ (15) [80]. In all cases, the [(1,6-diene) PdL] complexes were more effective as catalysts than mixtures of $\left[\mathrm{Pd}(\mathrm{OAc})_{2}\right]$ or $\left[\mathrm{Pd}_{2}(\mathrm{dba})_{3}\right]$ and the phosphines.

Fu reported that complex $\left[\mathrm{Pd}\left(\mathrm{PCy}_{3}\right)_{2}\right](\mathbf{1 6})$, formed in situ from $\left[\mathrm{Pd}(\mathrm{OAc})_{2}\right]$ and $\mathrm{PCy}_{3}$, catalyzes the room-temperature coupling of primary alkyl bromides that posses $\beta$-hydrogens with alkyl-BBN (BBN $=9$-borabicyclo[3.3.1]nonane) [82]. A similar complex, formed from $\left[\mathrm{Pd}_{2}(\mathrm{dba})_{3}\right]$ and $\mathrm{PCy}_{3}$ (1:2 ratio of $\mathrm{Pd}$ to phosphine), allowed coupling of primary alkyl chlorides that posses $\beta$-hydrogens with alkylboranes [83]. Complex 16, and related complexes with other monodentate bulky phosphines, catalyzed the Kumada coupling of alkyl chlorides [84].

For the coupling of primary alkyl tosylates, the bulkier phosphine $\mathrm{P}(t \mathrm{Bu})_{2} \mathrm{Me}$ gave the best results [85]. The reactive complex is probably $\left[\mathrm{Pd}\left(\mathrm{P}(t \mathrm{Bu})_{2} \mathrm{Me}\right)_{2}\right](\mathbf{1 7})$. As expected, the oxidative addition of the alkyl tosylate to $\operatorname{Pd}(0)$ results in predominant inversion of configuration, while the transmetallation occurs with retention [85]. Complex $\left[\mathrm{Pd}\left(\mathrm{P}(t \mathrm{Bu})_{2} \mathrm{Me}\right)_{2}\right.$ ] also catalyzes the room-temperature coupling of primary alkyl bromides that possess $\beta$-hydrogens with boronic acids [86]. Complex 18 , the oxidative addition product of an alkyl bromide to 17 , has been isolated and structurally characterized [86] (Scheme 1-11).

Menzel and Fu also found that the Stille coupling of alkenyl stannanes with alkyl bromides that possess $\beta$-hydrogens is also possible at room temperature with $\left[\mathrm{Pd}\left(\mathrm{P}(\mathrm{Bu})_{2} \mathrm{Me}\right)_{2}\right]$ as the catalyst [87]. In this case, the addition of fluoride was required to enhance the reactivity of the stannane.

Interestingly, while with isolated $\left[\mathrm{Pd}\left(\mathrm{P}(t \mathrm{Bu})_{3}\right)_{2}\right]$ (19) high temperatures are required for the activation of aryl halides in the Suzuki coupling [88], as well the amination [72d] and Heck reaction [71a, 89], the complex that results from the reaction of $\left[\mathrm{Pd}_{2}(\mathrm{dba})_{3} \cdot \mathrm{dba}\right]$ and one equivalent of $\mathrm{P}(t \mathrm{Bu})_{3}$ allows these reactions

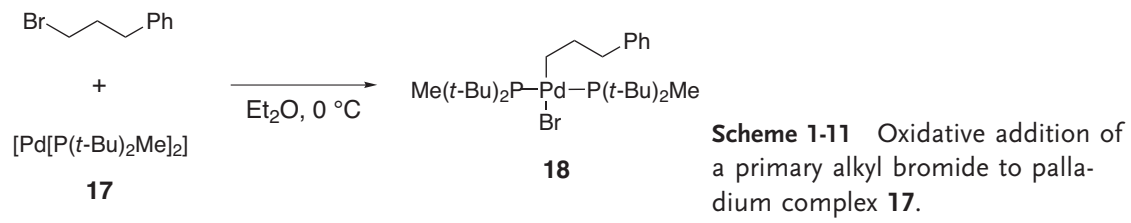




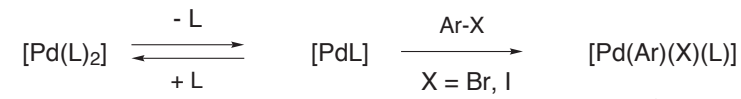

20: $\mathrm{L}=\mathrm{P}(\mathrm{o}-\mathrm{Tol})_{3}$

22: $\mathrm{L}=\mathrm{PCy}(t-\mathrm{Bu})_{2}$

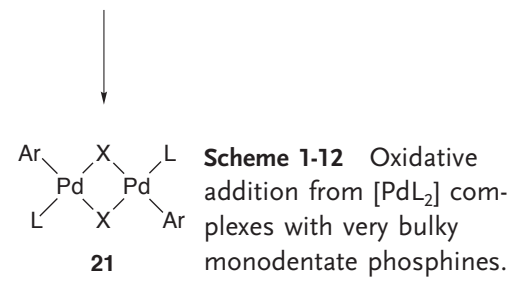

to be performed at room temperature [66d, 89, 90-92]. Remarkably, under these conditions, aryl chlorides coupled in preference to aryl triflates [90]. Less bulky $\mathrm{PCy}_{3}$ could be used for the Suzuki reaction of aryl triflates. Related bulky phosphines also allow to carry out Suzuki couplings under relatively mild conditions [77].

The $\mathrm{Pd} / \mathrm{P}(\mathrm{Bu})_{3}$ system was also applied by Fu for the Stille reaction with aryl electrophiles [93]. As an activator for the stannane, CsF was used. Mechanistic studies suggested that a palladium monophosphine complex [PdL] is the active catalyst in the cross-coupling of aryl halides [89].

In accord with the mechanistic observations made by $\mathrm{Fu}$ on the $\mathrm{Pd} / \mathrm{P}(\mathrm{Bu})_{3}$ catalyzed couplings [89, 90], Hartwig proposed that the oxidative addition of aryl bromide to complex $\left[\mathrm{Pd}\left(\mathrm{P}(0-\mathrm{Tol})_{3}\right)_{2}\right](20)$ involved prior dissociation of a phosphine ligand giving a 12e-complex $\left[\mathrm{Pd}\left(\mathrm{P}(o-\mathrm{Tol})_{3}\right)\right][94-96]$ (Scheme 1-12). The addition of a second equivalent of ligand to the dimeric complexes of type 21 promotes the reductive elimination with formation of ArX. This process involves the dissociative ligand substitution and cleavage to the monomers, prior to the reductive elimination [97].

Brown, Jutand, and co-workers reported that $\left[\mathrm{Pd}\left(\mathrm{PCy}_{3}\right)_{2}\right](\mathbf{1 6})$ reacts with PhOTf by an associative mechanism [98]. Reaction of $\mathrm{PhI}$ with 16 or $\left[\mathrm{Pd}\left(\mathrm{PCy}_{2}(t \mathrm{Bu})\right)_{2}\right]$ also proceeded associatively. In contrast, complexes $\left[\mathrm{Pd}\left(\mathrm{P}(t \mathrm{Bu})_{3}\right)_{2}\right](\mathbf{1 9})$ or $\left[\mathrm{Pd}\left(\mathrm{PCy}(t \mathrm{Bu})_{2}\right)_{2}\right]$ (22) (Scheme 1-12), with bulkier phosphines, behaved like $\left[\mathrm{Pd}\left(\mathrm{P}\left(0-\mathrm{Tol}_{3}\right)\right)_{2}\right](20)$.

Hartwig also reported the isolation of formally tricoordinated, T-shaped, Pd(II) complexes 23 in the oxidative addition of $\mathrm{Ar}-\mathrm{X}$ to $\left[\mathrm{PdL}_{2}\right]$ or $[\mathrm{Pd}(\mathrm{dba}) \mathrm{L}]$ bearing very bulky phosphines (Scheme 1-13) [99].

Two of these complexes, 23a-b, were structurally characterized (Scheme 1-14). In both cases, agostic interactions with $\mathrm{C}-\mathrm{H}$ bonds of the phosphine were suggested

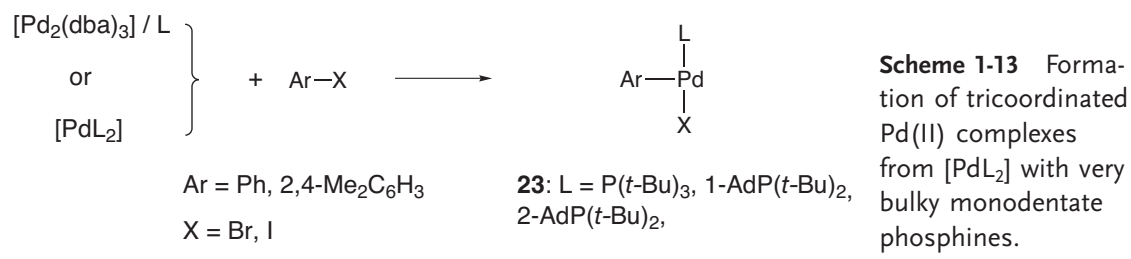




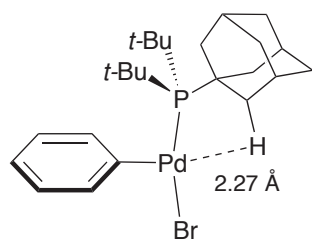

$\mathrm{P}-\mathrm{Pd}-\mathrm{Br}$ angle $=162.6^{\circ}$

23a

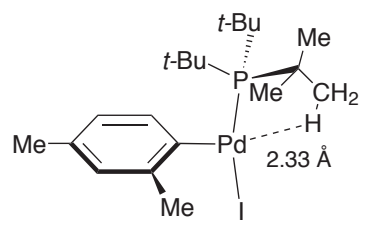

P-Pd-I angle $=164.6^{\circ}$

23b
Scheme 1-14 Simplified models for the solid-state structures of complexes 23a and $23 \mathrm{~b}$.

[99], which resemble distorted square-planar Pd(II) complexes. A related platinum complex shows a seemingly three-coordinate Pt(II) core [100], although the metal is actually stabilized by an agostic interaction with one of the methyl groups of the phosphine ligand.

In support of the involvement of $\left[\mathrm{Pd}\left(\mathrm{PR}_{3}\right)\right]$ in the oxidative addition, $\mathrm{Pd}(\mathrm{I})$ dimers 24 and 25 have been found to catalyze the room-temperature amination and Suzuki couplings of aryl chlorides and bromides [101] (Scheme 1-15). These palladium dimers decompose to form the palladium dibromide $\left[\mathrm{Pd}\left(\mathrm{PR}_{3}\right) \mathrm{Br}_{2}\right]$ and a highly reactive $\mathrm{Pd}(0)$ complex $\left[\mathrm{Pd}\left(\mathrm{PR}_{3}\right)\right]$.

In the quest for coordinatively unsaturated palladium catalysts, the more radical approach uses "ligandless conditions" [102, 103] following work pioneered by Beletskaya [14b, 104]. However, the mechanism of cross-coupling reactions under these conditions is not known [105]. In this context, it is worth mentioning that ferrocenylmethylphosphine-containing polymer and $\left[\mathrm{Pd}(\mathrm{OAc})_{2}\right]$, which allow the formation of local, highly reactive $[\mathrm{PdL}]$ active sites, catalyze the coupling of aryl chlorides with arylboronic acids at room temperature [106].

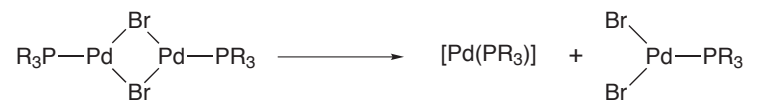

24: $\mathrm{PR}_{3}=\mathrm{P}(1-\mathrm{Ad})(t-\mathrm{Bu})_{2}$

25: $\mathrm{PR}_{3}=\mathrm{P}(t-\mathrm{Bu})_{3}$

Scheme 1-15 Formation of highly reactive $[\mathrm{PdL}] \mathrm{com}$ plexes from $\mathrm{Pd}(\mathrm{I})$ dimers.

Scrambling with the phosphine

Exchange between $\mathrm{R}$ residues on palladium and the phosphine ligand can take place under very mild conditions (Scheme 1-16), which may lead to homocoupling [107-109]. Contradictory mechanistic results emerged from the study of the methyl/phenyl and the aryl/phenyl exchange. In the first study with complexes such as 26 [107], the rate was not affected by added $\mathrm{PPh}_{3}$. However, in the second example, the rearrangement of aryl palladium(II) complexes 27 was almost completely inhibited by $\mathrm{PPh}_{3}[108]$.

The contradiction has been addressed by Novak [110], who demonstrated that the aryl-aryl interchange reaction of $\left[\mathrm{PdArL}_{2} \mathrm{X}\right]$ proceeds first through a reductive elim- 


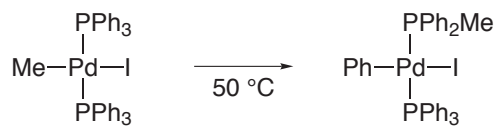

26

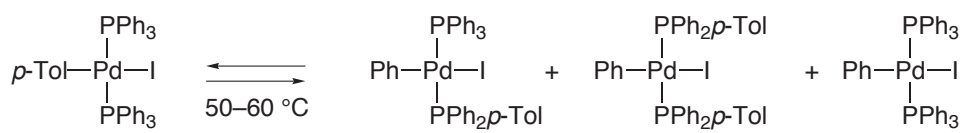

27

Scheme 1-16 Scrambling of $\mathrm{R}$ with the phosphine ligands.

ination to form a phosphonium salt, followed by an oxidative addition of a different phosphorus-carbon bond. The interchange and phosphonium salt formation reactions alike are facilitated by predissociation of either phosphine or iodide.

\subsubsection{N-Heterocyclic Carbenes as Ligands}

Although $\mathrm{N}$-heterocyclic carbenes have demonstrated their utility as ligands in a variety of cross-coupling reactions [111], very few mechanistic investigations have been carried out thus far on the reactions with complexes bearing this type of ligand. Nevertheless, the oxidative addition of $\left[\mathrm{PdL}_{2}\right](\mathrm{L}=$ heterocyclic carbene) to aryl halides has been shown to furnish the expected trans-square planar complexes such as 28 and 29 [112, 113] (Scheme 1-17).<smiles></smiles><smiles>O=[N+]([O-])c1ccc(I)c(I)c1</smiles><smiles>CC1=C(C)N(C)C(P(I)(I)(c2ccc([N+](=O)[O-])cc2)C2N(C)C(C)=C(C)N2C)N1C</smiles>

28<smiles>COc1ccc(Cl)cc1</smiles>

29

Scheme 1-17 Oxidative addition products with $\mathrm{N}$-heterocyclic carbenes as ligands. 


\subsubsection{Palladacycles as Catalysts}

Many palladacycles have also been described as useful catalysts of cross-coupling and related reactions [114-122]. However, strong evidence has been accumulated that indicates that the palladacycles merely act as a reservoir of $\mathrm{Pd}(\mathrm{II})$, that requires reduction to $\operatorname{Pd}(0)$ to enter into the catalytic cycle $[119,120,123]$. Thus, in a detailed study of the Heck reaction catalyzed by palladacycles 30 and 31 (Scheme 1-18), Pfaltz and Blackmond concluded that the resting state of the catalyst within the catalytic cycle was a $\mathrm{Pd}(\mathrm{II})$ intermediate derived from oxidative addition, while the majority of Pd remained outside the catalytic cycle as a dimer in equilibrium with the oxidative addition species [123].

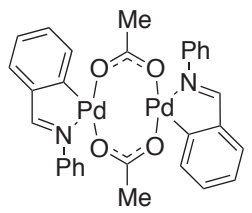

30

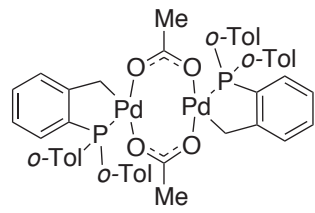

31
Scheme 1-18 Representative Pd(II)-palladacycles used as precatalysts in cross-coupling and Heck reactions.

On the involvement of $\mathrm{Pd}(\mathrm{IV})$ in catalytic cycles

There is strong evidence for the formation of $\mathrm{Pd}(\mathrm{IV})$ intermediates by oxidative addition of alkyl halides to Pd(II) complexes [124, 125]. However, C(sp²)-X electrophiles, such as aryl halides, are much less reactive in the oxidative addition to $\mathrm{Pd}(\mathrm{II})$ complexes and, therefore, the formation of $\mathrm{Pd}(\mathrm{IV})$ species from these electrophiles is less likely. Indeed, there is no experimental evidence for such a process in the organometallic chemistry of Pd(II) complexes [126, 127].

A genuine coupling based on a group $10 \mathrm{M}(\mathrm{II}) / \mathrm{M}(\mathrm{IV})$ catalysis is probably involved in the nickel-catalyzed coupling of alkyl halides and tosylates with Grignard reagents discovered by Kambe [128] (Scheme 1-19). A similar system has been developed for the catalytic $\mathrm{C}-\mathrm{C}$ bond-forming reaction using nonactivated alkyl fluorides by coupling of alkyl Grignard reagents with $\mathrm{CuCl}_{2}$ or $\mathrm{NiCl}_{2}$ as the catalysts [128b].

In this system, a bis $\left(\eta^{3}\right.$-allyl)nickel(II) complex such as 32 formed by an oxidative dimerization of butadiene is probably involved in the catalytic cycle (Scheme 1-19). The oxidative addition of the alkyl halide or tosylate to the electron-rich intermediate 33 may form $\mathrm{Ni}(\mathrm{IV})$ complex 34 . A reductive elimination of 34 would then form the C-C bond and the active $\mathrm{Ni}(\mathrm{II})$ complex. 


$$
\begin{aligned}
& \mathrm{R}-\mathrm{X}+\mathrm{R}^{\prime}-\mathrm{MgX} \stackrel{\text { cat. } \mathrm{NiCl}_{2}}{\mathrm{R}} \mathrm{R}-\mathrm{R}^{\prime} \\
& \mathrm{R}=\mathrm{alkyl} \\
& \mathrm{X}=\mathrm{Cl}, \mathrm{Br} \text {, OTs }
\end{aligned}
$$

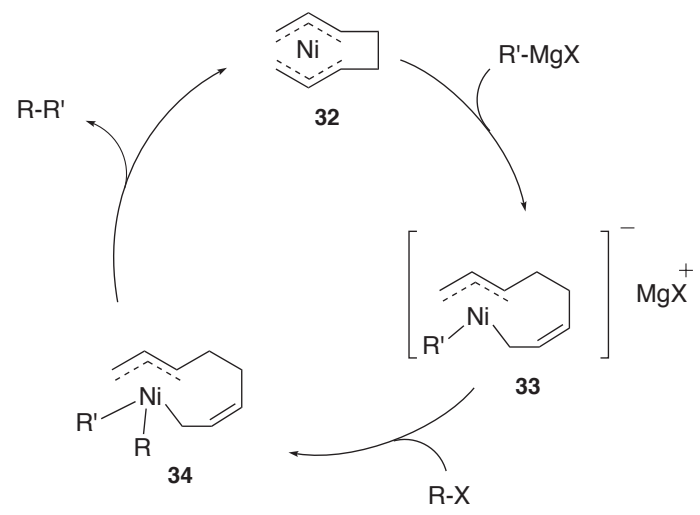

Scheme 1-19 Ni-catalyzed coupling of alkyl halides and tosylates with Grignard reagents.

\subsubsection{Oxidative Addition of Stannanes to $\operatorname{Pd}(0)$}

Oxidative addition of certain stannanes to $\mathrm{Pd}(0)$ complexes also appears to be a possible pathway. Thus, alkynyl stannanes have been shown to react with $\operatorname{Pd}(0)$ complexes $[129,130]$. Additionally, the $\operatorname{Pd}(0)$-catalyzed reaction of allyl stannanes with alkynes has been found to afford allylstannylation products 35 (Scheme 1-20) [131]. A likely mechanism involves an oxidative addition of the allyl stannanes to $\operatorname{Pd}(0)$ to give $\left(\eta^{3}\right.$-allyl)palladium complexes 36a (Scheme 1-20). In this transformation, the usually nucleophilic allyl stannanes behave as electrophiles. Complexes of type $\mathbf{3 6 b}$ are probably formed by transmetallation of $\left(\eta^{3}\right.$-allyl)palladium complexes with hexamethylditin [132]. An oxidative addition to form complexes 36b has been proposed in the $\mathrm{Pd}(0)$-catalyzed carboxylation of allyl stannanes with $\mathrm{CO}_{2}$ [133]. Although complexes of type $\mathbf{3 6}$ have never been isolated as stable species, studies on the intramolecular reaction of allyl stannanes with alkynes and theoretical calculations provide support to the formation of these complexes by the oxidative addition of allyl stannanes to $\operatorname{Pd}(0)$ [134].

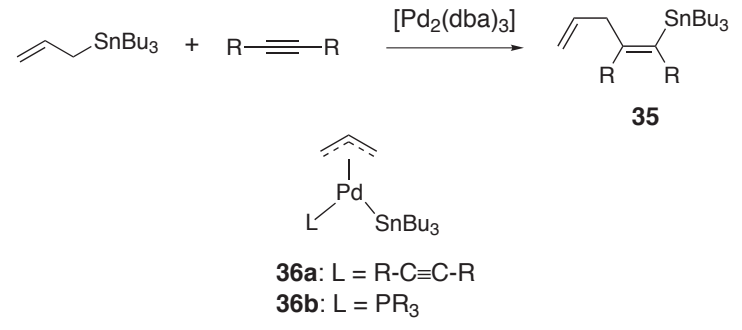

Scheme 1-20 Allyl-stannylation of alkynes by oxidative addition of allyl stannanes to $\mathrm{Pd}(0)$. 
1.1 .3

Transmetallation in the Stille Reaction

\subsubsection{Isolation of the Transmetallation Step}

The transmetallation step has been studied intramolecularly with systems 37 ( $\mathrm{X}=$ $\mathrm{Br}, \mathrm{I})$, which undergo oxidative addition to $\left[\mathrm{Pd}\left(\mathrm{PPh}_{3}\right)_{4}\right]$ to give intermediate complexes that suffered transmetallation to form palladacycles 38 [135] (Scheme 1-21). The isolated palladacycles 38 are stable species that do not reductively eliminate due to the high ring strain of the expected four-membered ring heterocycles.

Intermediate 39 was isolated from the oxidative addition of $37(\mathrm{X}=\mathrm{I}, \mathrm{R}=\mathrm{Me})$ to the $\operatorname{Pd}(0)$ complex $[\mathrm{Pd}(\mathrm{dba})(\mathrm{dpp})]$. Presumably, the steric bulk of the dppf ligand does not favor the necessary alignment of the Pd-I and C-Sn bonds in the transition state of the transmetallation (cyclic transmetallation; see Section 1.1.3.3). However, smooth transmetallation was observed in the presence of $\mathrm{Ag}_{2} \mathrm{CO}_{3}$ to form palladacycle 40 [135b]. Under these conditions, replacement of the iodo by a carbonato ligand might facilitate transmetallation through an open transition state. Analogous models have been applied for the study of the transmetallation of silanes [136] as well as the related transmetallation of stannanes with Pt(II) [137].

The reaction between pincer triflato complex 41 and 2-(tributylstannyl)furan led to transmetallation derivative 42 as a stable compound (Scheme 1-22) [138]. When the reaction was performed at low temperature, an intermediate cationic complex 43 was observed with the furan $\eta^{2}$-coordinated to the palladium center.

Lo Sterzo has observed a different precoordination complex in the transmetallation of bimetallic complex 44 with alkynyl stannanes (Scheme 1-23) [139], one of the key steps of the palladium-catalyzed metal-carbon bond formation [139, 140]. Pentacoordinated palladium complex 45 was detected spectroscopically and shown to evolve to 46 by first eliminating $\mathrm{PPh}_{3}$.

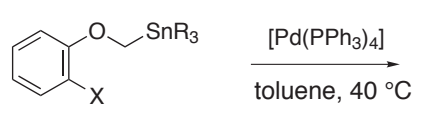

37: $\mathrm{X}=\mathrm{Br}, \mathrm{I} ; \mathrm{R}=\mathrm{Me}, \mathrm{Bu}$

[Pd(dba)dppf], toluene, $23^{\circ} \mathrm{C}$

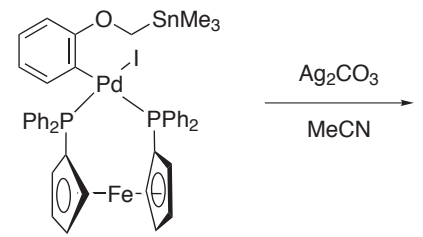

39

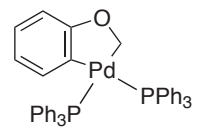

38

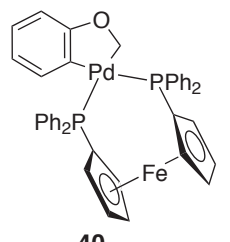

Scheme 1-21 Isolation of transmetallation intermediates in the Stille reaction. 


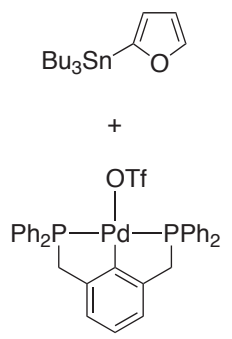

41

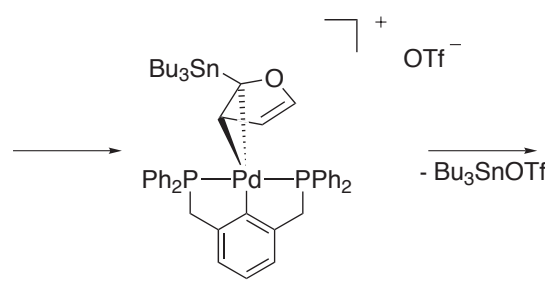

43<smiles>Pc1occc1P(c1ccccc1)P(c1ccccc1)c1ccccc1</smiles>

42

Scheme 1-22 Isolation of a $\eta^{2}$-furyl palladium(II) complex in a transmetallation reaction.<smiles>COc1ccccc1[PH](I)(c1ccccc1)[PH](I)(c1ccccc1)c1ccccc1</smiles><smiles>C[14CH3]</smiles>

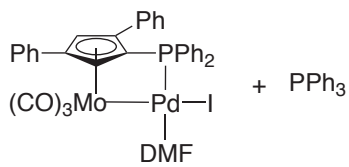

47
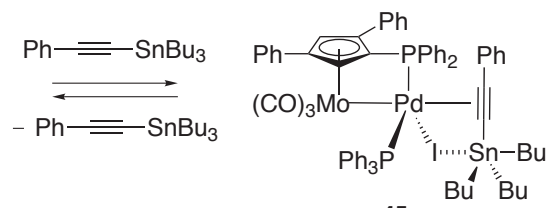

45
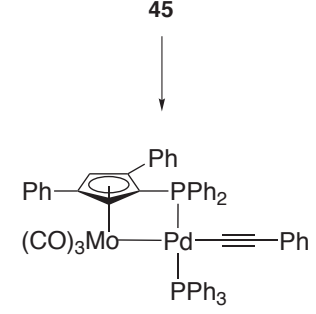

46
Scheme 1-23 Transmetallation intermediates in the palladium-catalyzed metalcarbon bond formation.

Complex 44 exchanged $\mathrm{PPh}_{3}$ in $\mathrm{DMF}$ to form complex 47 and the corresponding iodo-bridged palladium dimer [139]. The involvement of this complex in a parallel transmetallation with the organostannane was proposed to support the dissociative mechanism for the transmetallation reaction [139].

\subsubsection{Dissociative Mechanistic Proposals}

It has been shown that the addition of neutral ligand L retards the coupling [141, 142]. In addition, ligands such as trifurylphosphine [143, 144] and triphenylarsine $[19,142,145]$, which are of lower donicity that $\mathrm{PPh}_{3}$, have a beneficial effect in the Stille reaction. These results have been taken as an indication that ligand dissociation is a key step in the transmetallation.

Thus, the simplified mechanism in Scheme 1-24, involving a dissociative X-for$\mathrm{R}^{2}$ substitution $(\mathrm{X}=\mathrm{I}, \mathrm{Br})$ with preservation of the configuration at Pd, was proposed for vinyl and aryl stannanes. It was assumed that 48 cannot undergo transmetallation, probably because it is too electron-rich, and ligand dissociation occurs previous to the transmetallation to form coordinatively unsaturated 49 or, more likely, 50, with a coordinated solvent molecule, S. More electrophilic complex $\mathbf{5 0}$ 


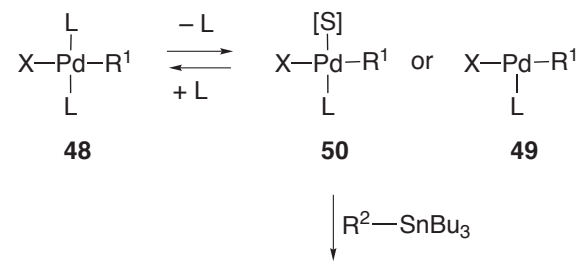

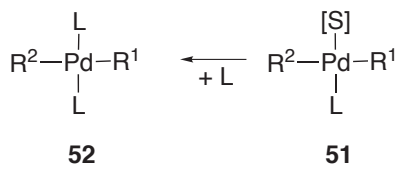

Scheme 1-24 Mechanistic scheme for the dissociative transmetallation in the Stille reaction.

would then be involved in the transmetallation with the stannane to give $\mathbf{5 1}$, which could then afford trans complex $\mathbf{5 2}$.

Although the above interpretation has been disputed (see Sections 1.1.3.3 and 1.1.3.4), a dissociative transmetallation probably takes place with complexes bearing very bulky ligands. Thus, Hartwig found that for the transmetallation of dimers $\left[\operatorname{PdArBr}\left\{\mathrm{P}(\mathrm{o}-\mathrm{Tol})_{3}\right\}\right]_{2}(53)[96]$ the rate depended on the square root of the concentration of dimer (Scheme 1-25). This is consistent with a dissociative mechanism, in which T-shaped monomers 54 [141] react with the organostannane, presumably through 55, to give the coupled product Ar-R.

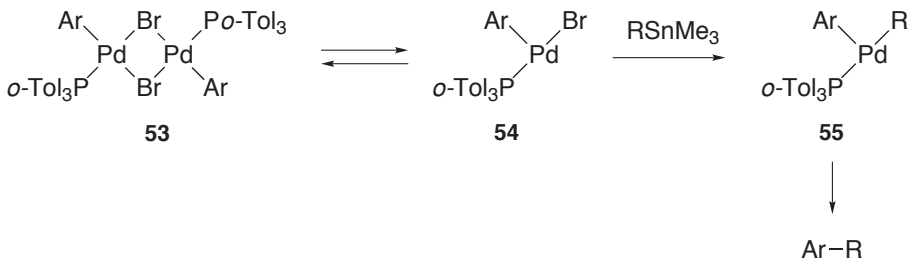

Scheme 1-25 Transmetallation of T-shaped Pd(II) complexes with organostannanes.

\subsubsection{Cyclic Associative Transmetallation}

The dissociative proposals for the transmetallation assume that the trans configuration of complex 48 to give a trans-[ $\left.\operatorname{PdR}^{1} \mathrm{R}^{2} \mathrm{~L}_{2}\right]$ complex (52) is preserved (Scheme 1-24). Since the reductive elimination of $R^{1}-R^{2}$ is well established to occur on cis derivatives, a rapid isomerization of trans- to cis-[PdR $\left.{ }^{1} \mathrm{R}^{2} \mathrm{~L}_{2}\right]$ needs to be postulated (Scheme 1-2). An important additional problem with mechanisms based on ligand dissociation is that this type of substitution is rare for $\operatorname{Pd}(\mathrm{II})$ [146].

The observed dependence on the ligand concentration has recently been explained by Espinet within the framework of an associative mechanism (Scheme $1-26)[147,148]$. These studies were based on kinetic measurements of the palla- 


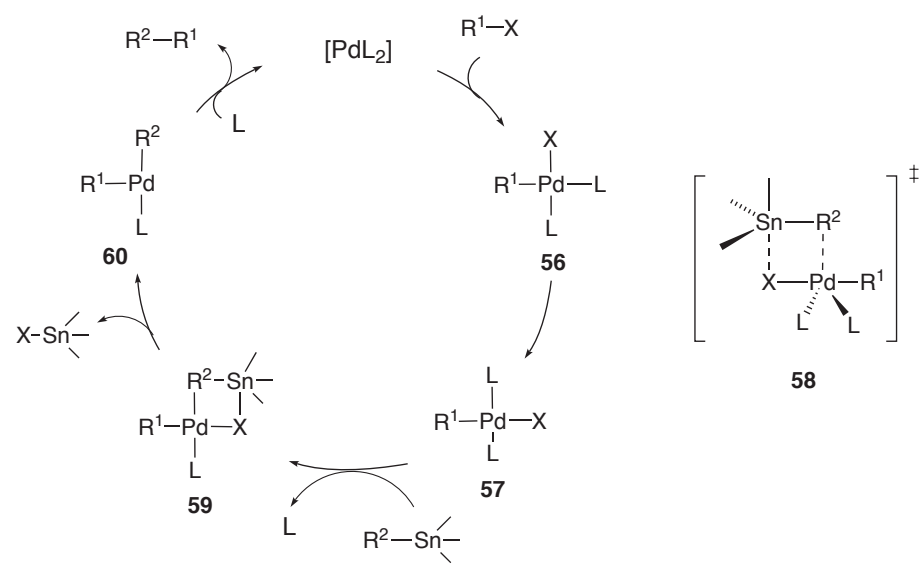

Scheme 1-26 Mechanism of the Stille reaction based on a cyclic associative transmetallation.

dium-catalyzed coupling with substrates such as 1,3-dichloro-2,4,6-trifluoro-5-iodobenzene $\left(\mathrm{C}_{6} \mathrm{Cl}_{2} \mathrm{~F}_{3} \mathrm{I}\right)$ and vinyl- or (4-methoxyphenyl)tributyltin. The proposed mechanism also takes into account the known formation of cis-complexes 56 in the oxidative addition, which subsequently isomerize to trans-57.

Importantly, the transmetallation involves an associative L-for- $\mathrm{R}^{2}$ substitution, through transition state $\mathbf{5 8}$, to give bridged intermediate 59 ( $\mathrm{S}_{\mathrm{E}} 2$ reaction). This intermediate evolves to give directly a cis- $\mathrm{R}^{1} / \mathrm{R}^{2}(\mathbf{6 0})$ rather than a trans- $\mathrm{R}^{1} / \mathrm{R}^{2}$ arrangement in the resulting complex, from which the coupled product will immediately eliminate the organic product $R^{1}-R^{2}$.

The proposal of Scheme 1-26 explains the observed dependence on L, and produces immediately the cis-arrangement needed for rapid $\mathrm{R}^{1}-\mathrm{R}^{2}$ coupling. The known inverse relationship between ligand donor ability and transmetallation rate $[2,17,141,142]$ supports the dissociative model because ligands of modest donicity (such as $\mathrm{AsPh}_{3}$ ) would be more easily displaced in an associative substitution process.

The coupling of $\mathrm{PhI}$ and vinyl tributyl stannane with $\left[\mathrm{Pd}(\mathrm{dba})\left(\mathrm{AsPh}_{3}\right)_{2}\right]$ in dimethylformamide (DMF) has been recently examined by Amatore and Jutand [50, 149]. This study revealed that, under those conditions, the species preceding the transmetallation steps is complex 61, bearing a DMF as a ligand (Scheme 1-27). In this case, the relatively weak ligand $\mathrm{AsPh}_{3}$ is displaced by the coordinating solvent DMF. The alkenyl stannane then substitutes the DMF ligand to form complex 62, which undergoes transmetallation (associative cyclic mechanism) as shown in Scheme 1-26. A similar process might be operating in the system studied by Lo Sterzo (see Scheme 1-23) [139].

Although, as stated above (Section 1.1.3.2), when very bulky ligands are used, a dissociative mechanism probably operates through T-shaped intermediates such as $54[96,141]$ (Scheme 1-28), these intermediates may then evolve by a $\mathrm{S}_{\mathrm{E}} 2$ (cyclic) transmetallation with the organostannane via 63 . 

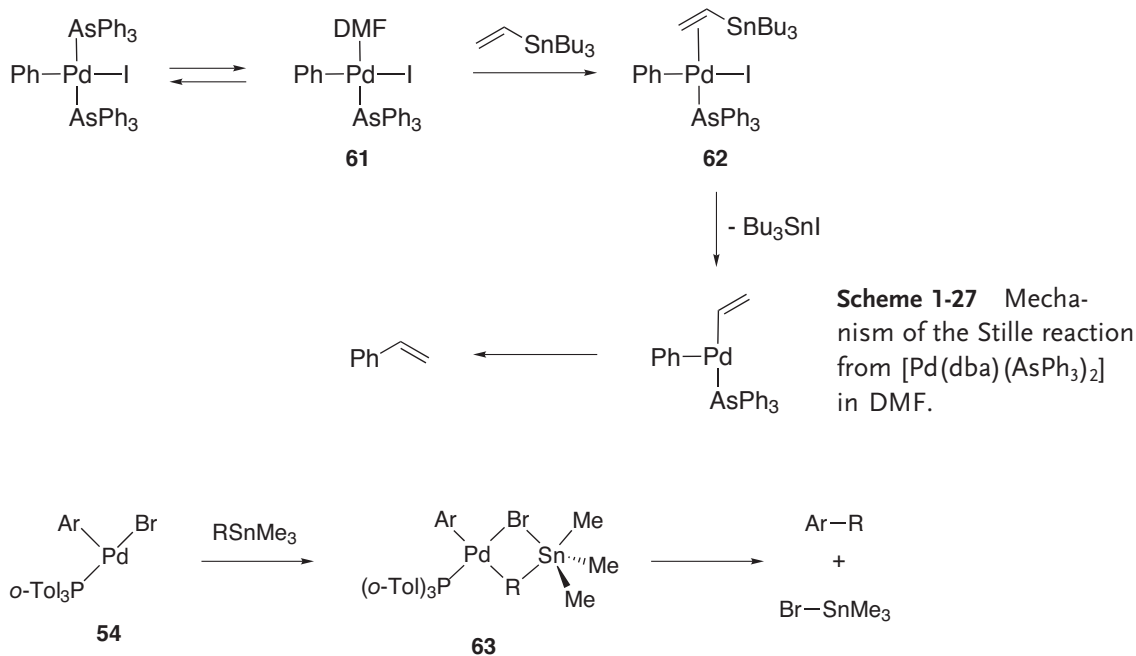

Scheme 1-28 Transmetallation from T-shaped Pd(II) complex 54.

\subsubsection{Open Associative Transmetallation}

Scheme 1-26 pertains to the coupling of aryl or vinyl halides under the experimental conditions most commonly applied for the Stille reaction, involving the use of moderately coordinating solvents, palladium complexes with monodentate ligands of normal steric bulk, and ratios L:Pd $>2: 1$. This mechanism predicts retention of configuration at the carbon of the group transferred from the nucleophilic stannane.

A study of the coupling of aryl triflates with organostannanes by Espinet led to the conclusion that an open transition state operates in cases where no bridging groups are available on the coordination sphere of $\mathrm{Pd}(\mathrm{II})$ to produce a cyclic intermediate $[150,151]$. The $\mathrm{S}_{\mathrm{E}} 2$ (open) transmetallation mechanism, proceeding through transition state 64, is summarized in Scheme 1-29. This is the only possible path in the absence of bridging ligands, but can also operate in their presence. It implies $\mathrm{X}$-for- $\mathrm{R}^{2}$ or L-for- $\mathrm{R}^{2}$ replacement at the Pd center, leading competitively to cis and trans arrangements to give $\mathbf{6 5}$ and $\mathbf{6 6}$, and produces inversion of configuration at the $\alpha$-carbon transferred from the stannane. This mechanism should be favored by the use of polar, coordinating solvents, lacking bridging ability. It might also operate in the presence of an excess of $\mathrm{L}$ and with easily leaving anionic ligands lacking bridging ability, in which case transmetallation proceeds from cationic complexes 67. This mechanism is also followed in the coupling aryl triflates with vinyl tributyl stannane in the presence of dppe as the ligand [151].

The fact that the transmetallation step in the Stille reaction can follow two different paths $-\mathrm{S}_{\mathrm{E}} 2$ (cyclic) and $\mathrm{S}_{\mathrm{E}} 2$ (open) - has important stereochemical consequences, as this transformation determines the stereochemical outcome of the overall coupling reaction for $\mathrm{C}\left(\mathrm{sp}^{2}\right)-\mathrm{X}$ electrophiles. Therefore, retention of configuration would be expected for a $\mathrm{S}_{\mathrm{E}} 2$ (cyclic) pathway, while a $\mathrm{S}_{\mathrm{E}} 2$ (open) mechanism 


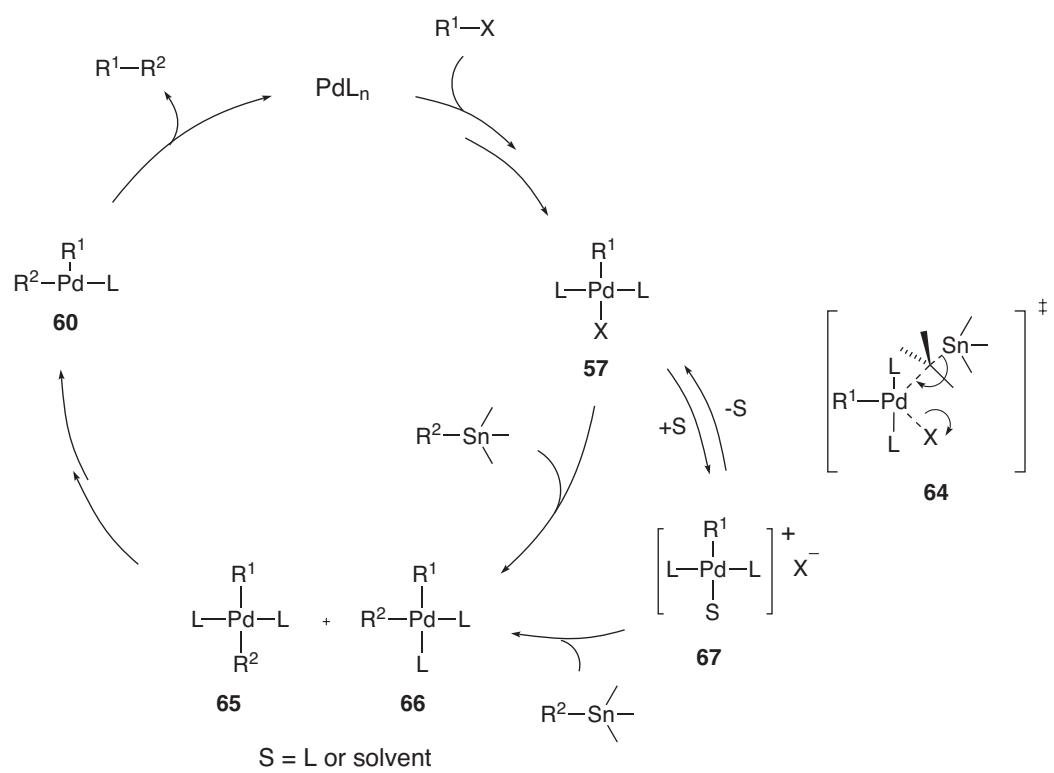

Scheme 1-29 Mechanism of the Stille reaction based on an open associative transmetallation.

would result in overall inversion of configuration. This clarifies the contradictory stereochemical results reported in the literature. Thus, Falck reported $98 \%$ retention of configuration in the coupling of chiral $\alpha$-alkoxystannanes with acyl chlorides in toluene [22], which would proceed by a cyclic pathway. On the other hand, Labadie and Stille found inversion $(\geq 65 \%)$ in the coupling of a chiral benzylic stannane to an acyl chloride in HMPA [21]. In this last example, the use of highly polar and coordinating solvent favors the open pathway, even in the presence of potentially bridging chloride ligand.

The open-associative mechanism probably operates in the Stille reaction carried out in the presence of additives such as fluorides [93] and hydroxide anion [152]. Similarly, coordination of tin to the nitrogen of benzyl amines (68) [153] and stannatrane derivatives $(69)[154,155]$ (Scheme 1-30) presumably led to transmetallation by an $\mathrm{S}_{\mathrm{E}} 2$ (open) mechanism.

A different type of coordination is involved in a system developed by Yoshida for the selective transfer of the $\mathrm{Me}_{3} \mathrm{SiCH}_{2}$ - group from 70 [156] (Scheme 1-31). In this case, coordination of the pyridine nitrogen to $\mathrm{Pd}(\mathrm{II})$ as shown in $\mathbf{7 1}$ favors the intramolecular transmetallation through a $\mathrm{S}_{\mathrm{E}} 2$ (cyclic) intermediate. However, a trans to cis isomerization is now required for the reductive elimination of complex 72 .

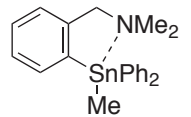

68

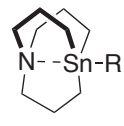

69
Scheme 1-30 Internal coordination to tin favors transmetallation to $\mathrm{Pd}(\mathrm{II})$. 


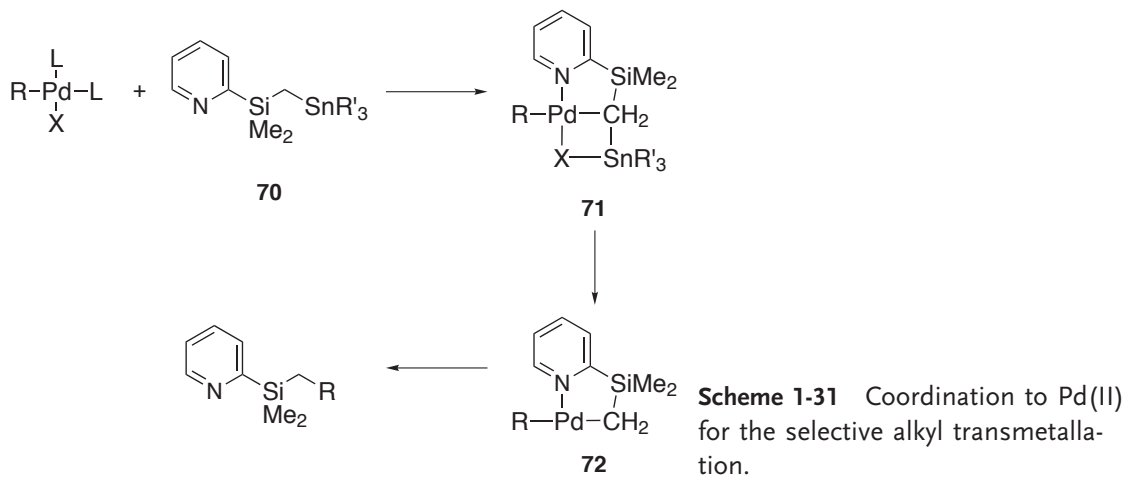

\subsubsection{The "Copper Effect" and Copper-Catalyzed Couplings}

A remarkable phenomenon in Stille couplings is the effect of the addition of $\mathrm{CuI}$ or other $\mathrm{Cu}(\mathrm{I})$ salts, which is known to accelerate some couplings catalyzed by [PdL 4 [17, 19, 22, 157-159].

The "copper effect" has been rationalized by Espinet within the framework provided by the associative mechanism. Accordingly, CuI does not promote the dissociation of $\mathrm{L}$ from trans-[ $\left.\mathrm{PdR}^{1} \mathrm{IL}_{2}\right]$ [159], but it captures part of the free neutral ligand L released during the oxidation of $\left[\mathrm{PdL}_{4}\right]$ that yields the species actually undergoing transmetallation, trans-[PdR $\left.\mathrm{IL}_{2}\right]$, plus $2 \mathrm{~L}$. Therefore, the effect of $\mathrm{CuI}$ is to mitigate the "auto-retardation" produced by the presence of free $\mathrm{L}$ on the rate determining associative transmetallation [160].

Farina and Liebeskind [159] already proposed that in very polar solvents, a $\mathrm{Sn} / \mathrm{Cu}$ transmetallation could take place, leading to the in situ formation of organocopper species - a proposal that later developed into effective coupling systems. Thus, Piers demonstrated that the intramolecular coupling of alkenyl iodides with alkenyl stannanes can be carried out by using $\mathrm{CuCl}$ under stoichiometric conditions $[161,162]$. Better results were later obtained by using other $\mathrm{Cu}(\mathrm{I})$ salts, which allow the reaction to proceed under catalytic conditions [163-169].

\subsubsection{Transmetallation in the Suzuki Reaction}

Due to the low nucleophilicity of the borane reagents (compared with organostannanes, for example), the Suzuki reaction requires the use of base in order to take place. Stronger bases such as $\mathrm{NaOH}, \mathrm{TlOH}$, and $\mathrm{NaOMe}$ perform well in THF/ $\mathrm{H}_{2} \mathrm{O}$ solvent systems, whereas weaker bases such as $\mathrm{K}_{2} \mathrm{CO}_{3}$ and $\mathrm{K}_{3} \mathrm{PO}_{4}$ are usually more successful in DMF. The base is involved in several steps of the catalytic cycle, most notably in the transmetallation process.

Soderquist has performed detailed mechanistic studies on the coupling of trialkyl boranes and alkoxy(dialkyl) boranes with aryl and alkenyl electrophiles (Scheme 1-32) [170]. This study allowed the determination of the stereochemistry of the transmetallation step $[170,171]$ and the role of the base in the catalytic cycle. 
<smiles></smiles><smiles>[R7]OB1C2CCC(CC2)C1OPCC</smiles>

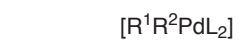<smiles>[R][R]C(C)C(C)C(C)C</smiles>

$$
\left[\mathrm{R}^{1} \mathrm{R}^{2} \mathrm{PdL}_{2}\right]
$$

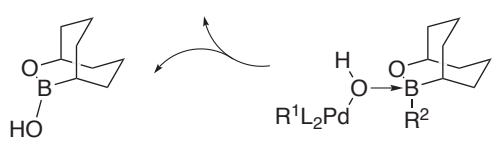

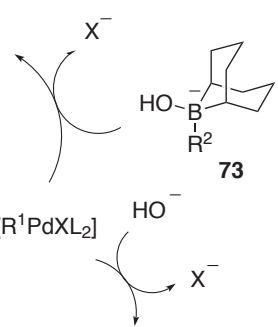

$\left[\mathrm{HOPdR}^{1} \mathrm{~L}_{2}\right]$<smiles>CCC(C)C</smiles>

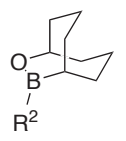

74
Scheme 1-32 Catalytic cycles for the coupling of trialkylboranes (upper cycle) and alkoxo derivatives (lower).

The main role of base is to generate a more reactive borate 73 by coordination of hydroxide to boron, which will react with the intermediate R-Pd(II)-X complex. On the other hand, in the case of the alkoxoboranes 74 , the base also reacts with the intermediate $\mathrm{R}-\mathrm{Pd}(\mathrm{II})-\mathrm{X}$ derivatives to form the more reactive $\mathrm{R}-\mathrm{Pd}(\mathrm{II})-\mathrm{OH}$ species (Scheme 1-32). Several intermediates in the Suzuki coupling of bromopyridines with arylboronic acid have been identified by using in situ analysis of the reaction by electrospray mass spectrometry [172].

Complexes of other metals have been recently described which catalyze other Suzuki-type reactions. Thus, platinum complexes catalyze the coupling between arylboronic acids and aryl halides [137], and $\left[\mathrm{Ni}\left(\mathrm{PCy}_{3}\right)_{2} \mathrm{Cl}_{2}\right]$ is effective in the cross-coupling of arylboronic acids and aryl tosylates [173]. In this case, the usual mechanism involving oxidative addition of the aryl tosylate to $\left[\mathrm{Ni}\left(\mathrm{PCy}_{3}\right)_{2}\right]$, followed by transmetallation and reductive elimination has been proposed. The study of the effects of the substituents on the electrophile and the boronic acid indicate that transmetallation is the rate-determining step. The mechanism of the Pd-catalyzed homo-coupling of arylboronic acids has also been studied [174].

\subsubsection{Transmetallation in the Hiyama Reaction}

The lower reactivity of the $\mathrm{Si}-\mathrm{C}$ bond requires the use of activating reagents to enhance the reactivity of silanes and to promote the Si-Pd transmetallations. Fluoride is the common additive, although other nucleophiles such as hydroxide, metal oxides and alkoxides are also effective [175]. Fluoride converts the starting silanes into pentacoordinate fluorosilicates, which are the actual transmetallation reagents.

Transmetallation of alkenyl silanes takes place with retention of the double bond configuration, as in other cross-coupling reactions [176]. Due to the lower transmetallation rate, competing 1,2-insertion of the alkene in the intermediate organopal- 


$$
\begin{array}{cl}
\mathrm{Re}=\mathrm{CF}_{3}, \mathrm{COCH}_{3}, \mathrm{~F}, \mathrm{H}, \mathrm{CH}_{3}, \mathrm{OEt} & \text { ipso / cine from } 93: 7 \text { to } \\
\mathrm{TBAF}, \mathrm{THF}, 60^{\circ} \mathrm{C} & \text { ipso }
\end{array}
$$

Scheme 1-33 Hiyama reaction involving alkene insertion (Heck-type) prior to transmetallation.<smiles>CC(=O)c1ccc(O)cc1</smiles><smiles>C[C@H](F)c1ccccc1</smiles>

$38 \%$ e.e., $(S)$

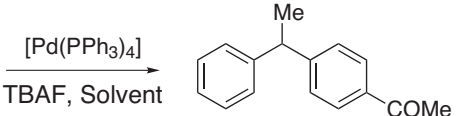

THF : $31 \%$ e.e., $(S)$

HMPA-THF $(1: 20): 8 \%$ e.e., $(R)$

Scheme 1-34 Solvent effect on the stereoselectivity of Si-Pd alkyl transmetallation.

ladium complex (Heck-type) may take place, which affects the regioselectivity of the Hiyama reaction in some cases [177] (Scheme 1-33). This results in cine-substitution - a process that has also been observed in Stille coupling reactions of some hindered alkenyl stannanes [178].

Hiyama studied the stereoselectivity of alkyl transmetallation in the $\left[\mathrm{Pd}\left(\mathrm{PPh}_{3}\right)_{4}\right]-$ catalyzed reaction of aryl triflates with enantiomerically enriched (S)-1-phenylethyltrifluorosilane in the presence of TBAF [179]. At $50^{\circ} \mathrm{C}$, retention of the configuration resulted, but at higher temperatures, a linear decrease of the degree of retention takes place and finally, inversion is observed above $75^{\circ} \mathrm{C}$. A significant solvent effect was also observed. Thus, the reaction in THF resulted in retention. On the other hand, inversion was found in HMPA-THF (1:20) (Scheme 1-34).

The retention of configuration at low temperatures in THF can be explained assuming a fluorine-bridged $\mathrm{S}_{\mathrm{E}}$ 2(cyclic) transition state (75), analogous to that proposed for the Stille reaction (see Scheme 1-26) formed from a pentacoordinate silicate (Scheme 1-20).

In polar solvents or at higher temperatures, the fluorine-silicon bridge would be cleaved to switch the transition-state model to the $S_{\mathrm{E}} 2$ (open) (76), thus resulting in inversion. On the other hand, open and cyclic $\mathrm{S}_{\mathrm{E}} 2^{\prime}$ mechanisms have been pro-

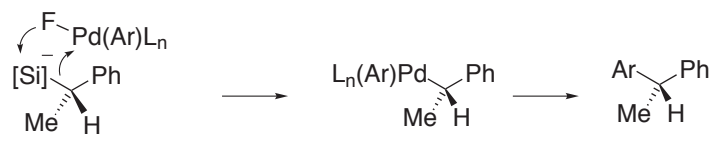

75

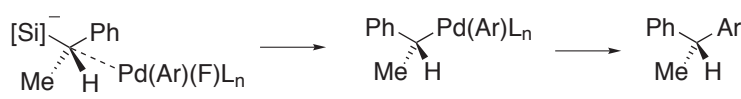

Scheme 1-35 Possible mechanisms for alkyl Si-Pd transmetallation reactions. 
posed to justify the observed stereochemistry in the $\gamma$-selective cross-coupling of allyl silanes [180].

1.1 .4

\section{Reductive Elimination}

\subsubsection{The Effect of Bidentate Ligands}

Formation of T-shaped intermediates from square-planar complexes greatly accelerates the reductive elimination of $\left[\mathrm{Pd}(\mathrm{L})_{2} \mathrm{RR}^{\prime}\right]$ complexes [26]. The same is true for complexes bearing bidentate diphosphanes [23, 24, 26]. The reductive elimination of a series of $\left[\mathrm{Pd}(\mathrm{L}-\mathrm{L}) \mathrm{Me}_{2}\right]$ complexes revealed that only complex 77a with $\mathrm{Cy}_{2} \mathrm{PCH}_{2} \mathrm{PCy}_{2}$, with the smallest bite-angle, leads to a smooth elimination of ethane (Scheme 1-36). The reductive elimination from these complexes is most probably preceded by dissociation of one of the diphosphine arms to form a T-shaped intermediate [181]. The resulting $\operatorname{Pd}(0)$ complex [Pd(L-L)] undergoes dimerization to form complex 78. Complexes $77 \mathbf{b}-\mathbf{d}$, with more stable chelates, do not eliminate ethane under mild conditions.

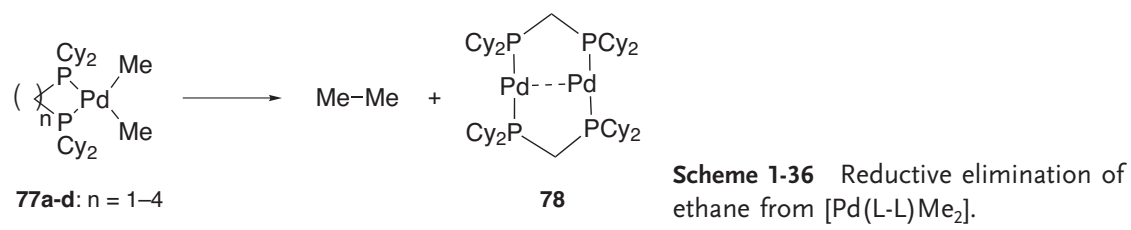

On the other hand, for a series of $\left[\mathrm{Pd}(\mathrm{L}-\mathrm{L}) \mathrm{Me}_{2}\right]$ with L-L = dppp, dppf, and 1,1'-bis(diphenylphosphino)ruthenocene (dppr), the fastest elimination was observed with the ligand with the largest bite angle [182, 183]. This effect on the reductive elimination was also found by Hayashi [184] and van Leeuwen [185] in the palladium-catalyzed cross-coupling reaction of Grignard reagents with aryl halides.

\subsubsection{Coupling with Allylic Electrophiles: The Slow Reductive Elimination}

The rate-determining step in the coupling of aryl halides or triflates with aryl- or alkenyl stannanes can be either the transmetallation or the oxidative addition, depending on the exact circumstances of the reaction [147, 150]. On the other hand, in the coupling of allylic electrophiles, the reductive elimination step might become rate-determining. Schwartz has shown that the coupling of allylic halides and allylic organometallics does not proceed unless electron-withdrawing olefins such as maleic anhydride are used [186, 187]. Kurosawa also noted the promoting effect of electron-withdrawing olefins on the reductive elimination [188].

Transmetallation of $\left(\eta^{3}\right.$-allyl)palladium complexes with aryl stannanes gives aryl allyl palladium complexes 79 (Scheme 1-37) [189]. The reductive elimination from these complexes is slow, and controls the reaction outcome. In order to produce 


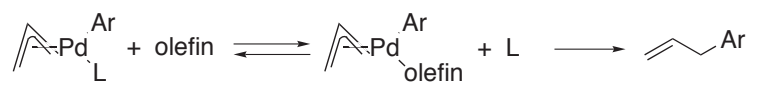

79
Scheme 1-37 Reductive

elimination aryl allyl palladium complexes promoted by $\pi$-acceptor alkenes.

an efficient coupling, coordination of a promoter of reductive elimination such as $p$-benzoquinone or other electron-withdrawing olefin to form $\mathbf{8 0}$, is very effective. Under catalytic conditions, the allyl electrophile acts as the electron-withdrawing olefin itself [189].

$\operatorname{Bis}\left(\eta^{3}\right.$-allyl)palladium complexes are not productive intermediates in the coupling of allyl stannanes with allyl carboxylates or halides [190], as these complexes do not show any tendency to undergo reductive elimination [191, 192]. In the presence of phosphine ligands, $\left(\eta^{1}\right.$-allyl $)\left(\eta^{3}\right.$-allyl)palladium complexes are formed [193-195]. On the other hand, addition of diphosphines gives bis $\left(\eta^{1}\right.$-allyl)palladium diphosphine complexes [196], which undergo smooth reductive elimination at low temperatures [197]. Calculations also support the idea that the most favorable pathway for the reductive elimination involves bis $\left(\eta^{1}-\right.$ allyl $)$ palladium complexes bearing two phosphine ligands (Scheme 1-38) [198]. Interestingly, the formation of a bond between $\mathrm{C} 3$ and $\mathrm{C}^{\prime}$ of the allyls in 81 is significantly preferred to form 82 (Scheme 1-38), regardless of the syn or anti arrangement of both allyl moieties, compared with the formation of $\mathrm{C} 1-\mathrm{C} 1$ ' or $\mathrm{C} 1-\mathrm{C} 33^{\prime}$ bonds.<smiles>C=CC[Pb](P)(P)CC=C</smiles>

81

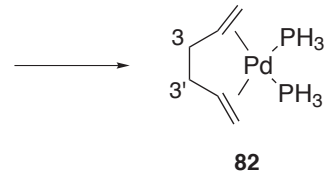

Scheme 1-38 Most favored reductive elimination of bis $\left(\eta^{\top}\right.$-allyl)palladium complexes.

1.2

Formation of C,C-Bonds in the Palladium-Catalyzed $\alpha$-Arylation of Carbonyl Compounds and Nitriles

The palladium-catalyzed $\alpha$-arylation of ketones has become a useful and general synthetic method [67]. Initial studies required preformed zinc [199] or tin enolates [200]. By contrast, Ni-mediated [201] or -catalyzed couplings were also identified. A major development of the reaction has occurred since 1997 based on the use of new catalysts with electron-rich alkyl phosphines and $N$-heterocyclic carbenes as ligands $[111,202]$. The reactions resemble cross-coupling processes in which the enolates behave as the nucleophilic organometallic reagents (Scheme 1-39).

The reductive elimination step has been studied on isolated Pd complexes containing both an aryl group and an enolate as ligands. A suitable choice of phosphine is necessary to afford complexes sufficiently stable to be isolated and suffi- 


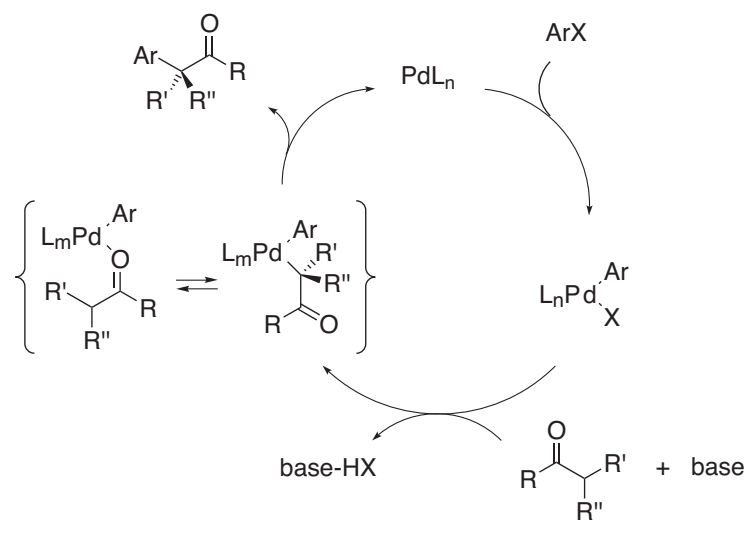

Scheme 1-39 General catalytic cycle for the $a$-arylation of carbonyl compounds.

ciently reactive to undergo reductive elimination. In the case of ketone enolate complexes, both C- and O-bound species are formed, depending on the type of ketone and the phosphine ligand. Reductive elimination rates of complexes for a series of 1,2-bis(diphenylphosphino)benzene (dppBz) aryl palladium complexes with different $\mathrm{C}$-enolate ligands groups parallel the nucleophilicity of the $\mathrm{R}$ group (Scheme 1-40).

As far as the influence of the phosphine ligand in the catalyzed reactions is concerned, $\mathrm{P}(\mathrm{Buu})_{3}$ is effective in most cases. The rates of the reductive elimination of enolate complexes containing this and other bulky phosphines are higher, and the scope of many couplings catalyzed by complexes of these ligands is broader. Recently, it has been shown that a catalytic quantity of phenol causes a remarkable increase in the efficiency of ketone enolate arylation [203].

The formation of a $\left(\mathrm{PCy}_{3}\right)$-Pd- $\mathrm{L}(\mathrm{L}=N$-heterocyclic carbene) has been proposed as the catalytically active species in the aryl amination and $\alpha$-arylation of ketones by Nolan in a system starting from a palladacycle containing a $N$-heterocyclic carbene [204].

Copper-catalyzed arylation of malonates [205] and other activated methylene compounds (malononitrile, ethyl cyanoacetate) [206] has been also reported. It is likely that the catalytically active species is a $\mathrm{Cu}(\mathrm{I})$ enolate.

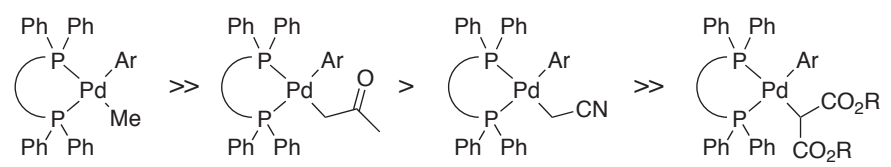

Scheme 1-40 Relative reactivity in the reductive elimination for a series of dppBz-aryl palladium complexes. 
1.3

Key Intermediates in the Formation of C-X $(X=N, O, S)$ bonds in Metal-Catalyzed Reactions

$\operatorname{Pd}(\mathrm{II})$ complexes formed by oxidative addition of organic electrophiles to $\operatorname{Pd}(0)$ may react with amines, alcohols or thiols in the presence of base to give the key amido, alkoxide, or sulfide complexes. These complexes will, in turn, afford the $\mathrm{C}-\mathrm{X}(\mathrm{X}=\mathrm{O}, \mathrm{N}, \mathrm{S})$ containing organic products by reductive elimination $[65$, 207, 208]. The palladium-catalyzed cyanation of aryl halides [209] is most likely related mechanistically to these reactions.

The mechanism of the formation of the C-Pd-X complexes depends on the type of nucleophile. For the palladium-catalyzed reactions involving tin amides or tin thiolates, monophosphine-palladium complexes are involved as intermediates [141]. Bidentate phosphines are not effective in the amination of electrophiles involving tin amides [210].

The amination reactions involving amines as the nucleophiles in the presence of base are mechanistically different. Stoichiometric reactions of different arylpalladium complexes suggest that two different mechanisms may be involved in the formation of the amido species from the oxidative addition complexes. Thus, amine-containing arylpalladium complexes 83 formed by ligand substitution or by cleavage of dimeric species react with base to give organopalladium-amido derivatives 84 , which then suffer reductive elimination to give the aryl amines (Scheme 1-41) [94, 211].

Alternatively, alkoxides or silylamides may first coordinate the palladium precursor to form an intermediate that might react with the amine to form the required amido-aryl intermediate. Extensive kinetic studies on stoichiometric reaction models support the mechanism in Scheme 1-42, in which the amine cleaves the dimeric hydroxo complex 85 to give an amine intermediate 86 which would suffer intramolecular proton transfer to give 87 [212]. A similar process is proposed for a dppf derivative [213].

Detailed kinetic studies have been carried out by Blackmond and Buchwald under synthetically relevant conditions to study the mechanism of the amination of bromobenzene with primary and secondary amines using $\left[\operatorname{Pd}_{2}(\mathrm{dba})_{3}\right] /$ binap mixtures as well as preformed $\left[\operatorname{Pd}(\right.$ binap) $(\mathrm{dba})],\left[\mathrm{Pd}(\right.$ binap) $(p-\mathrm{Tol})(\mathrm{Br})]$, and $\left[\mathrm{Pd}(\text { binap })_{2}\right]$ complexes [214]. The presence of a significant induction period in the reaction was

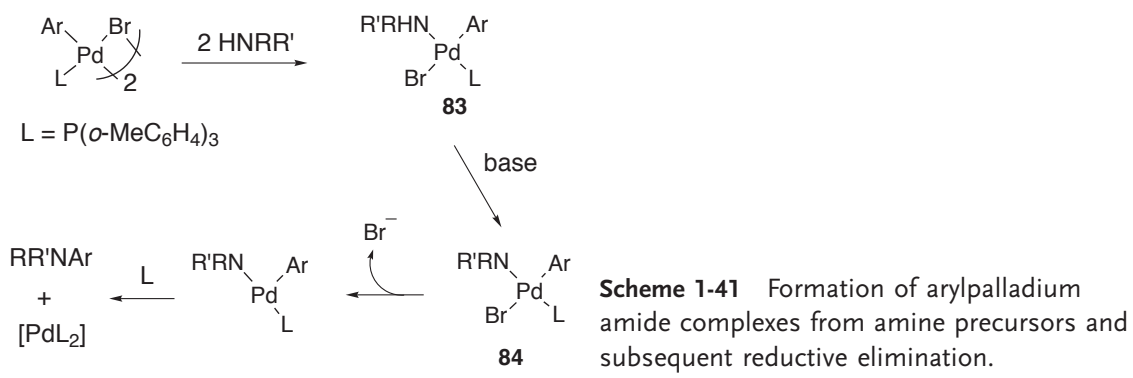




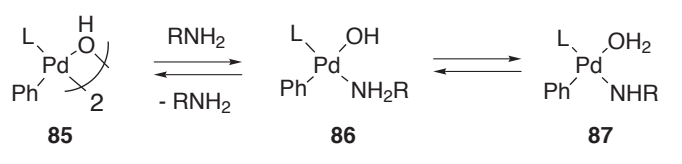

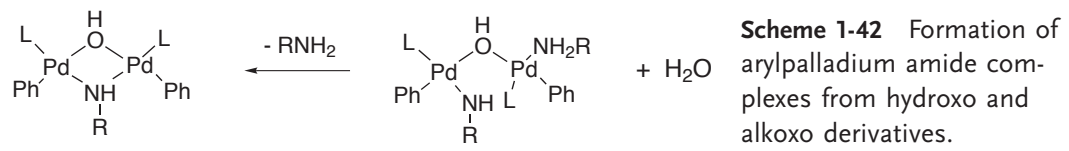

attributed to the slow activation of the catalytic precursor, resulting in an increase in the concentration of active species within the catalytic cycle. It was also confirmed that the bis-ligand complex $\left[\operatorname{Pd}(\text { binap })_{2}\right]$ does not play a role directly on the catalytic cycle [37, 90]. In addition to a pathway involving oxidative addition of the aryl halide to [ $\mathrm{Pd}($ binap)] as the first step, a pathway initiated by addition of the amine to $\operatorname{Pd}(0)$ was also proposed (Scheme 1-43). These results are consistent with deprotonation of the amine by base occurring only after both amine binding and oxidative addition have taken place. They also exclude the intermediacy of Pd-alkoxo complexes.

Thus, $\mathrm{Pd}(0)$ complexes of type [(RR'NH)Pd(binap)] are proposed to be the actual species which oxidatively add bromobenzene, as this process proceeds more rapidly than the direct oxidative addition on the $\mathrm{Pd}(0)$ complex with no coordinated amine [214].

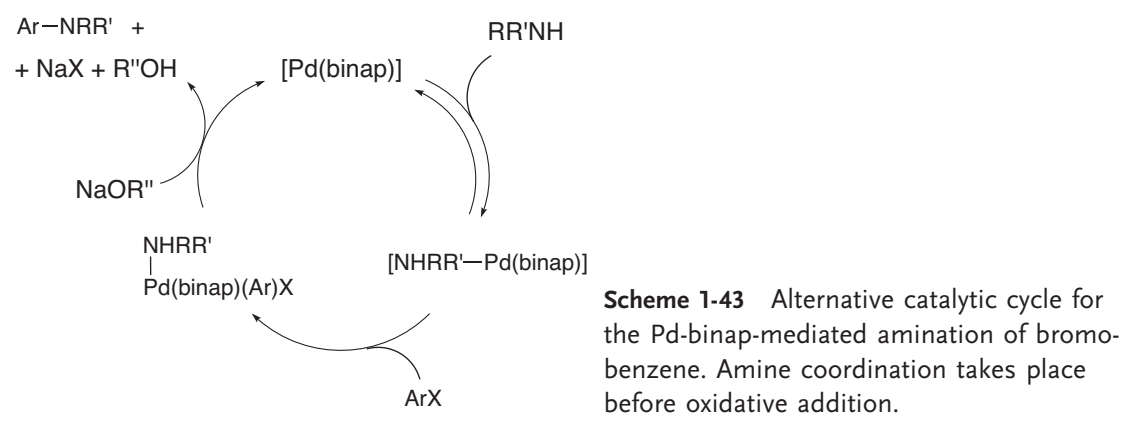

1.3.1

Reductive Elimination of C-N, C-O, and C-S Bonds From Organopalladium(II) Complexes

Reductive elimination of amine and ethers is the key bond-forming step in the catalytic amination and etheration reactions. Kinetic studies on stoichiometric reactions from isolated amido and alkoxo organopalladium complexes have shed 


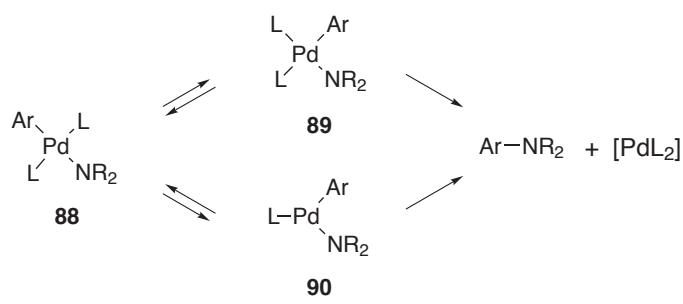

90
Scheme 1-44 Possible competing pathways for the $\mathrm{C}-\mathrm{N}$ reductive elimination from monodentate phosphine complexes.

light into the mechanism by identifying the actual species involved and the factors controlling this process. The most extensively studied of these reactions is the reductive elimination of C-N bonds from amido arylpalladium complexes [215, 216]. Both monomeric and dimeric species have been studied. In the case of monomeric complexes, some differences occur depending on the nature (mono- or bidentate) of the coordinating phosphines.

Thus, the reductive eliminations from trans-bis(triphenylphosphine) amido aryl complexes 88 showed first-order kinetics demonstrating that the reductive elimination takes place from monomeric species (Scheme 1-44). The dependence of the reaction rate on the concentration of added $\mathrm{PPh}_{3}$ is compatible with two competing mechanisms, one involving C-N bond formation to a cis 16-electron species 89 formed by isomerization of the trans derivative. The other mechanism involves initial reversible phosphine dissociation to give a 14 -electron, three-coordinate intermediate 90 that would undergo C-N bond formation (Scheme 1-44). Dimeric monophosphine complexes follow a dissociative pathway to give three-coordinate amido monomers, which suffer reductive elimination. The formation of the 14electron intermediates can be reversible or irreversible depending on the type of amine.

Amido organopalladium complexes containing bidentate phosphines have the cis configuration necessary to provide the reductive elimination. The zero-order dependence on the concentration of the added ligand is consistent with a direct concerted formation of the amine from the square planar complexes 91 (Scheme 1-45).

The influence on the reductive elimination of the substituents on both the amido and the $\mathrm{R}$ ligand has been studied on dppf model derivatives, as it appears to be a one-step process. The relative rates for elimination from different amido groups is alkylamido $>$ arylamido $>$ diarylamido. This trend implies that the more nucleophilic is the amido ligand, the more rapid the reductive elimination occurs. On the other hand, the presence of substituents on the aryl group also affects the reductive elimination rate, with electron-withdrawing groups accelerating the process. A similar behavior is observed for the reductive elimination of C-S bonds from aryl sulfide palladium complexes 92 (Scheme 1-46) [184a].

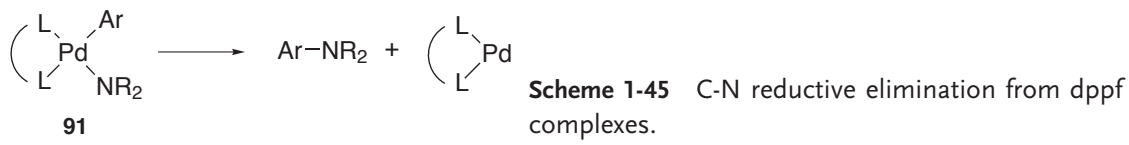




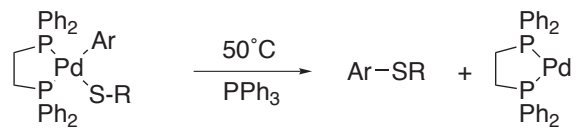

92
Scheme 1-46 Reductive elimination of C-S bonds.

The formation of ethers by reductive elimination from alkoxo organopalladium complexes faces some difficulties due to the lower nucleophilicity of the alkoxides compared with metal amides. The choice of suitable phosphine ligands is crucial for this type of reaction. Bulky aryldialkylphosphines allow the reaction of aryl chlorides, bromides, and triflates with a variety of isolated alkoxides [217] or, more interestingly, phenols and base [218] regardless of the substitution of the aryl groups. Intermediate alkoxo organopalladium complexes have been proposed to form by transmetallation from alkali metal alkoxides to organopalladium derivatives. The rate of the reductive elimination from these intermediates is significantly slower than the corresponding rate to form $\mathrm{C}-\mathrm{N}$ bonds. Two possible mechanisms exist for the intimate mechanism of the elimination. The first is the occurrence of a three-center transition state or an initial attack of the alkoxide on the aryl ipso carbon followed by elimination of the metal complex. The second mechanism would be more probable in the case of aryl electrophiles containing electron-withdrawing groups. It has been proposed that the bulkier ligands are necessary to destabilize the ground state of the intermediate $\left[\mathrm{L}_{n} \mathrm{Pd}(\mathrm{OR}) \mathrm{Ar}\right]$ complex, forcing the palladium bound aryl and alkoxide groups together. In this way, the complex is distorted toward the three-center transition state geometry [218a]. Stoichiometric reductive elimination reactions of $\mathrm{C}-\mathrm{N}$ and $\mathrm{C}-\mathrm{O}$ bonds from $\mathrm{Ni}$ complexes have also been described [219].

As it happens in the case of C-C cross-coupling reactions, $\beta$-hydrogen elimination is a competitive pathway in the palladium-catalyzed amination and etheration reactions. The conversion of the organic electrophiles to amines or ethers depends on the reductive elimination being faster than $\beta$-hydrogen elimination from amido or alkoxo intermediates. The extension of the undesired $\beta$-hydrogen elimination in C-N couplings has been studied on stoichiometric elimination reactions from amido arylpalladium complexes 93 (Scheme 1-47). The C-N $\beta$-hydrogen elimination has been proposed to take place also from amido complexes in some cases [220].

The final amount of $\beta$-hydrogen elimination products (arenes) depends on several factors [208a]. Thus, electron-withdrawing groups on the aryl ring increase the rate of the reductive elimination and minimize the formation of the arene.

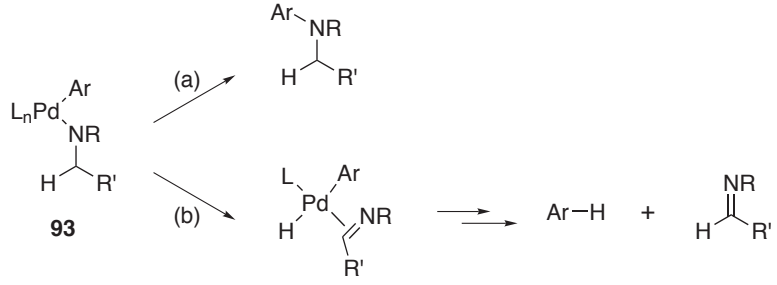

Scheme 1-47 Competitive pathways in the evolution of amido organopalladium complexes: (a) reductive elimination; (b) $\beta$-hydrogen elimination;
elimination. 
As it has been observed for etheration reactions, bulkier monophosphines enhance the rate of the $\mathrm{C}-\mathrm{N}$ reductive elimination. In the case of bidentate phosphines, the results are more difficult to rationalize. Thus, electron-poor derivatives of dppf produce more arene than dppf itself, albeit a more deficient metal center is thought to suffer an easier reductive elimination. Ligands with smaller bite angles yield less $\beta$ hydrogen elimination products, in contrast with the observed dependence for C-C reductive eliminations. Detailed studies have been performed on amido [221] and alkoxo [222] Ir(I) square-planar complexes, which indicate that reversible phosphine dissociation takes place prior to the $\beta$-hydrogen elimination for both amide and alkoxo complexes.

\subsection{2}

\section{Copper-Catalyzed Formation of C-X Bonds}

Other metal salts and complexes also catalyze the formation of C-N, C-O, and C-S bonds from organic electrophiles. Thus, a mixture of $\left[\mathrm{Ni}(\mathrm{COD})_{2}\right]$ and a bidentate phosphine catalyzes the formation of aryl ethers from aryl halides and alkoxides [223]. In some cases, the reactions occur under milder conditions and with higher yields than when catalyzed by Pd complexes.

By contrast, $\mathrm{Cu}(\mathrm{I})$ complexes have been reported to catalyze the formation of $\mathrm{C}-\mathrm{C}$, $\mathrm{C}-\mathrm{N}, \mathrm{C}-\mathrm{O}$ [224], and C-S [225] bonds. $\mathrm{Cu}$ (II) also catalyzes the reaction of boronic acids with phenols and amines under oxidative conditions to form Ar-O and Ar-N bonds [226]. Copper also catalyzes the halogen exchange [227] and the cyanation [228] of aryl halides. Interestingly, important differences exists between the Pdand Cu-catalyzed amination [229]. Thus, whereas palladium catalysts favor amination, copper complexes promote the reactions with carboxamides. In addition, anilines are better nucleophiles than alkylamines in the Pd-catalyzed amination, while the opposite occurs with $\mathrm{Cu}(\mathrm{I})$ as the catalyst [229]. Similar systems catalyze the coupling of secondary phosphines and phosphites with aryl and vinyl halides [230].

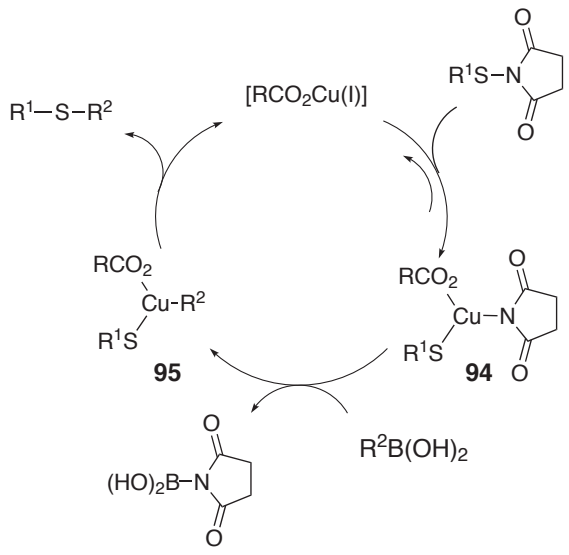

Scheme 1-48 Proposed mechanism for the $\mathrm{Cu}(\mathrm{I})$-catalyzed synthesis of thioethers from $N$-thioimides and boronic acids. 
Alkyl aryl sulfides might also be formed by the reaction of arylboronic acids and alkyl thiols in the presence of $\mathrm{Cu}(\mathrm{II})$ [230]. However, Liebeskind demonstrated that in this case the actual catalyst is $\mathrm{Cu}(\mathrm{I})$, which led to the development of an efficient method for the synthesis of thioethers by using $N$-thioimides [231]. For this transformation, the mechanism outlined in Scheme 1-48 has been proposed. Accordingly, an oxidative addition of the $\mathrm{N}$-thioimide to $\mathrm{Cu}$ (I) would form $\mathrm{Cu}$ (III) intermediate 94, which could transmetallate with the boronic acid to form 95. The reductive elimination from $\mathbf{9 5}$ then gives the thioether.

\section{4}

\section{Summary and Outlook}

A unified view emerges for the mechanism of cross-coupling reactions. The formation of C-X bonds with palladium catalysts loosely follows the same catalytic pathways of cross-coupling transformations. However, significant differences exist for both types of processes with regard to the rate-determining step(s) that depend on the nature of the electrophile, nucleophile, and the ligands on palladium.

The original proposal for cross-coupling reactions has evolved considerably. First, the oxidative addition of $\mathrm{C}\left(\mathrm{sp}^{2}\right)$-X electrophiles has been shown to give first cis-palladium(II) complexes, which subsequently isomerize to more stable trans complexes. Of greater significance is a clarification of the mechanism of the reaction between soft nucleophilic organometallic reagents and $\mathrm{Pd}(\mathrm{II})$. Based on studies on the Stille and Hiyama couplings, transmetallations to palladium appear to follow two major mechanisms. In poorly coordinating solvents and in the presence of bridging ligands, the associative $\mathrm{S}_{\mathrm{E}} 2$ (cyclic) mechanism operates, whereas the $\mathrm{S}_{\mathrm{E}}$ 2(open) mechanism proceeds when highly coordinating solvents are used. These two mechanisms pertain to conditions usually followed with palladium complexes coordinated to typical phosphine or arsine ligands. A third type of mechanism, which proceeds through T-shaped intermediates, most likely takes place when the starting $\mathrm{Pd}(0)$ catalyst bears two very bulky phosphine ligands such as $\mathrm{P}(0-\mathrm{Tol})_{3}$ or $\mathrm{P}(\mathrm{tBu})_{3}$.

When monodentate phosphine or arsine ligands are used, the transmetallation reaction leads directly to $\mathrm{T}$-shaped intermediates bearing two mutually cis $\mathrm{R}$ ligands (Schemes 1-26 and 1-29). Therefore, in general, there is no need for the trans- to cis-isomerization originally proposed for the Stille reaction (see Scheme 1-2) and later assumed for other transmetallation-based catalytic processes.

Many of the sound mechanistic investigations described have been conducted on palladium-catalyzed processes. Although recently developed reactions catalyzed by $\mathrm{Ni}(0), \mathrm{Pt}(0)$, or $\mathrm{Cu}(\mathrm{I})$ may follow similar schemes, additional mechanistic studies are needed to develop more efficient reactions. In this regard, it is also important to stress that, although studies conducted on isolated complexes are of major value in understanding these processes, more general mechanistic conclusions on these and related rather complex schemes will emerge from studies performed under realistic catalytic conditions. 


\section{Abbreviations}

$\begin{array}{ll}\text { Ad } & \text { adamantyl } \\ \text { BBN } & \text { 9-borabicyclo[3.3.1]nonane } \\ \text { binap } & \text { 2,2'-Bis(diphenylphosphino)-1,1'-binaphthyl } \\ \text { Cy } & \text { cyclohexyl } \\ \text { dba } & \text { dibenzylideneacetone } \\ \text { dippp } & \text { 1,3-bis(diisopropylphosphino)propane } \\ \text { dppBz } & \text { 1,2-bis(diphenylphosphino)benzene } \\ \text { dppe } & \text { bis(1,2-diphenylphosphino)ethane } \\ \text { dppf } & \text { bis(1,1'-diphenylphosphino)ferrocene } \\ \text { dppp } & \text { bis(1,3-diphenylphosphino)propane } \\ \text { dppr } & \text { bis(1,1'-diphenylphosphino)ruthenocene } \\ \text { HMPA } & \text { hexamethylphosphoric triamide } \\ \text { TBAF } & \text { tetrabutylammonium fluoride } \\ \text { TMEDA } & N, N, N^{\prime}, N^{\prime} \text {-tetramethylethylenediamine } \\ \text { TFP } & \text { tri-(2-furyl)phosphine }\end{array}$

\section{References}

[1] J. K. Stille, Angew. Chem. Int. Ed. 1986, 25, 508-524.

[2] V. Farina, in: Comprehensive Organometallic Chemistry II (Eds.: E. W. Abel, F. G. A. Stone, G. Wilkinson), Pergamon, Oxford, 1995, Vol. 12. Chapter 3.4., pp. 161-240.

[3] T. N. Mitchell, in: Metal-Catalyzed Cross-coupling Reactions (Eds.:

F. Diederich, P. J. Stang), Wiley-VCH, Weinheim, 1998, Chapter 4, pp. 167-202.

[4] (a) N. Miyaura, A. Suzuki, Chem. Rev. 1995, 95, 2457-2483; (b) A. Suzuki, in: Metal-Catalyzed Cross-coupling Reactions (Eds.: F. Diederich, P. J. Stang), Wiley-VCH, Weinheim, 1998, Chapter 2, pp. 49-97;

(c) S. R. Chemler, D. Trauner, S. J. Danishefsky, Angew. Chem. Int. Ed. 2001, 40, 4544-4568.

[5] J. Tsuji, Palladium Reagents and Catalysts, Wiley, Chichester, 1995.

[6] E.-I. Negishi, J. Organomet. Chem. 2002, 653, 34-40.

[7] (a) T. Hiyama, Y. Hatanaka, Pure Appl. Chem. 1994, 66, 1471-1478; Y. Hatanaka, T. Hiyama, Synlett 1991,
845-853; (b) T. Hiyama, in: MetalCatalyzed Cross-Coupling Reactions (Eds.: F. Diederich, P. J. Stang), Wiley-VCH, Weinheim, 1998, Chapter 10, pp. 421-454.

[8] S. E. Denmark, R. F. Sweis, Acc. Chem. Res. 2002, 35, 835-846.

[9] (a) K. Sonogashira, in: Metal-Catalyzed Cross-Coupling Reactions (Eds.: F. Diederich, P. J. Stang), Wiley-VCH, Weinheim, 1998, Chapter 5 , pp. 203-229; (b) R. R. Tywinski, Angew. Chem. Int. Ed. 2003, 42, 1566-1568.

[10] (a) M. Yamamura, I. Moritani, S. I. Murahashi, J. Organomet. Chem. 1975, 91, C39-C42; (b) J. F. Fauvarque, A. Jutand, Bull. Soc. Chim. Fr. 1976, 765-770; (c) A. Sekiya, N. Ishikawa, J. Organomet. Chem. 1976, 118, 349-354.

[11] E. Negishi, Acc. Chem. Res. 1982, 15, 340-348.

[12] Iron-catalyzed cross-couplings of alkyl-Grignards: (a) A. Fürstner, A. Leitner, Angew. Chem. Int. Ed. 2002, 41, 609-612; (b) A. Fürstner, A. Leitner, M. Méndez, H. Krause 
J. Am. Chem. Soc. 2002, 124, 1385613863.

[13] (a) R. F. Heck, Organic Reactions 1982, 27, 345-390; (b) R. F. Heck, in: Comprehensive Organic Synthesis (Ed.: B. M. Trost), Pergamon, Oxford, 1991, Vol. 4, Chapter 4.3, pp. 833-863.

[14] (a) A. de Meijere, F. E. Meyer, Angew. Chem. Int. Ed. 1994, 33, 23792411; (b) I. P. Beletskaya,

A. V. Cheprakov, Chem. Rev. 2000, 100, 3009-3066; (c) S. Bräse, A. de Meijere, in: Metal-Catalyzed CrossCoupling Reactions (Eds.: F. Diederich, P. J. Stang), Wiley-VCH, Weinheim, 1998, Chapter 3; pp. 99-166;

(d) J. T. Link, L. E. Overman, in: Metal-Catalyzed Cross-Coupling Reactions (Eds.: F. Diederich, P. J. Stang), Wiley-VCH, Weinheim, 1998, Chapter 6, pp. 231-269.

[15] M. Kosugi, K. Fugami, J. Organomet. Chem. 2002, 653, 50-53.

[16] D. Milstein, J. K. Stille, J. Am. Chem. Soc. 1978, 100, 3636-3638.

[17] V. Farina, V. Krishnamurthy, W. K. Scott, Org. React. 1997, 50, 1-676.

[18] (a) P. J. Stang, M. H. Kowalski, M. D. Schiavelli, D. Longford, J. Am. Chem. Soc. 1989, 111, 3347-3356; (b) P. J. Stang, M. H. Kowalski, J. Am. Chem. Soc. 1989, 111, 3356-3362.

[19] (a) V. Farina, G. P. Roth, Adv. MetalOrg. Chem. 1996, 5, 1-53; (b) V. Farina, Pure Appl. Chem. 1996, 68, 73-78.

[20] J. M. Brown, K. K. Hii, Angew. Chem. Int. Ed. 1996, 35, 657-659.

[21] J. W. Labadie, J. K. Stille, J. Am. Chem. Soc. 1983, 105, 6129-6137.

[22] (a) J. Ye, R. K. Bhatt, J. R. Falck, J. Am. Chem. Soc. 1994, 116, 1-5; (b) J. Ye, R. K. Bhatt, J. R. Falck, Tetrahedron Lett. 1993, 34, 8007-8010.

[23] K. Tatsumi, R. Hoffmann, A, Yamamoto, J. K. Stille, Bull. Chem. Soc. Jpn. 1981, 54, 1857-1867.

[24] F. Ozawa, T. Ito, Y. Nakamura, A. Yamamoto, Bull. Chem. Soc. Jpn. 1981, 54, 1868-1880.

[25] (a) D. Minniti, Inorg. Chem. 1994, 33, 2631-2634; (b) A. L. Casado,
J. A. Casares, P. Espinet, Organometallics 1997, 16, 5730-5736.

[26] A. Gillie, J. K. Stille, J. Am. Chem. Soc. 1980, 102, 4933-4941.

[27] (a) J. K. Stille, in: The Chemistry of the Metal-Carbon Bond; Hartley, F. R., Patai, S. Eds.; Wiley: Chichester, 1985, Vol. 2, Chapter 9, pp. 625-787;

(b) J. K. Stille, K. S. Y. Lau, Acc. Chem. Res. 1977, 10, 434-442.

[28] (a) H. Kurosawa, S. Ogoshi, Y. Kawasaki, S. Murai, M. Miyoshi, I. Ikeda, J. Am. Chem. Soc. 1990, 112, 2813-2814; (b) H. Kurosawa, H. Kajimura, S. Ogoshi, H. Yoneda, K. Miki, N. Kasai, S. Murai, I. Ikeda, J. Am. Chem. Soc., 1992, 114, 8417-8424.

[29] A. Vitagliano, B. Åkermark, S. Hansson, Organometallics 1991, 10, 2592-2599.

[30] A. Diefenbach, F. M. Bickelhaupt, J. Chem. Phys. 2001, 115, 4030-4040.

[31] I. Stary, P. Kocovsky, J. Am. Chem. Soc. 1989, 111, 4981-4982.

[32] C. Amatore, S. Gamez, A. Jutand, G. Meyer, M. Moreno-Mañas, L. Morral, R. Pleixats, Chem. Eur. J. 2000, 6, 3372-3376.

[33] J.-F. Fauvarque, F. Pflüger, M. Troupel, J. Organomet. Chem. 1981, 208, 419-427.

[34] A. Jutand, A. Moshleh, Organometallics 1995, 14, 1810-1817.

[35] (a) M. Portnoy, D. Milstein, Organometallics 1993, 12, 1655-1664;

(b) M. Portnoy, D. Milstein, Organometallics 1993, 12, 1665-1673.

[36] A review on the effect of ligand bite angles on organometallic reactions: P. W. N. M. van Leeuwen, P. C. J. Kamer, J. N. H. Reek, P. Dierker, Chem. Rev. 2000, 100, 2741-2769.

[37] C. Amatore, G. Broeker, A. Jutand, F. Khalil, J. Am. Chem. Soc. 1997, 119, 5176-5185.

[38] In the oxidative addition of allyl acetates to $[\mathrm{Pd}(\mathrm{L}, \mathrm{L})]$, the following order was observed: $\mathrm{dppb}>\mathrm{dppf}>\mathrm{PPh}_{3}$ : C. Amatore, S. Gamez, A. Jutand, Chem. Eur. J. 2001, 7, 1273-1280. 
[39] J. Vicente, A. Arcas, D. Bautista, P. G. Jones, Organometallics 1997, 16, 2127-2138.

[40] H. Urata, M. Tanaka, T. Fuchikami, Chem. Lett. 1987, 751-754.

[41] A. L. Casado, P. Espinet, Organometallics 1998, 17, 954-959.

[42] (a) Very often, this complex is described as $\left[\mathrm{Pd}(\mathrm{dba})_{2}\right]$. However, this is a dimetallic complex of formula $\left[\mathrm{Pd}_{2}(\mathrm{dba})_{3} \cdot \mathrm{dba}\right]$ : Y. Takahashi, T. Ito, S. Sakai, Y. Ishii, J. Chem. Soc., Chem. Commun 1970, 10651066. After recrystallization, the solvates $\left[\mathrm{Pd}_{2}(\mathrm{dba})_{3} \cdot(\mathrm{S})\right]\left(\mathrm{S}=\mathrm{CH}_{2} \mathrm{Cl}_{2}\right.$, $\mathrm{CHCl}_{3}$, benzene, toluene) are obtained: T.; Ukai, H. Kawazura, Y. Ishii, J. J. Bonnet, J. A. Ibers, J. Organomet. Chem. 1974, 65, 253-266;

M. C. Mazza, C. G. Pierpont, J. Chem. Soc., Chem. Commun. 1973, 207; M. C. Mazza, C. G. Pierpont, Inorg. Chem. 1974, 13, 1891-1895. See also: A. M. Echavarren, J. K. Stille, J. Organomet. Chem. 1988, 356, C35C37. (b) Tris(dibenzylideneacetone)palladium $(0),\left[\mathrm{Pd}(\mathrm{dba})_{3}\right]$, has been prepared by heating $\left[\mathrm{Pd}(\mathrm{dba})_{2}\right]$ with excess dba in benzene: M. C. Mazza, C. G. Pierpont, Inorg. Chem. 1973, 12, 2955-2959.

[43] The rates of oxidative addition starting from complexes $\left[\mathrm{Pd}_{2}(\mathrm{dba})_{3} \cdot \mathrm{dba}\right]$ or $\left[\mathrm{Pd}_{2}(\mathrm{dba})_{3} \cdot \mathrm{S}\right]$ are probably different, since the excess of dba may retard that reaction. However, the actual solvento complex $\left[\mathrm{Pd}_{2}(\mathrm{dba})_{3} \cdot \mathrm{S}\right]$ used in catalytic transformations is most probably not very significant. We refer to these complexes as $\left[\mathrm{Pd}_{2}(\mathrm{dba})_{3}\right]$.

[44] S. Park, D. Hidden, A. L. Rheingold, D. M. Roundhill, Organometallics 1986, 5, 1305-1311.

[45] C. Amatore, A. Jutand, Coord. Chem. Rev. 1998, 178-180, 511-528.

[46] C. Amatore, A. Jutand, G. Meyer, Inorg. Chim. Acta 1998, 273, 76-84.

[47] H. S. Sørensen, J. Larsen, B. S. Rasmussen, B. Laursen, S. G. Hansen, T. Skrydstrup, C. Amatore, A. Jutand, Organometallics 2002, 21, 5243-5253.

[48] C. Amatore, A. Jutand, F. Khalil, M. A. M’Barki, L. Mottier, Organometallics 1993, 12, 3168-3178.
[49] C. Amatore, A. Jutand, G. Meyer, H. Atmani, F. Khalil, F. O. Chahdi, Organometallics 1998, 17, 2958-2964.

[50] C. Amatore, A. Bucaille, A. Fuxa, A. Jutand, G. Meyer, A. Ndedi Ntepe, Chem. Eur. J. 2001, 7, 2134-2142.

[51] (a) C. Amatore, A. Jutand, Acc. Chem. Res. 2000, 33, 314-321; (b) A. Jutand, Eur. J. Inorg. Chem. 2003, 2017-2040.

[52] C. Amatore, A. Jutand, A. Suarez, J. Am. Chem. Soc. 1993, 115, 9531-9541.

[53] C. Amatore, A. Jutand, M. M'Barki, Organometallics 1992, 11, 3009-3013.

[54] C. Amatore, E. Carré, A. Jutand, M. M’Barki, Organometallics 1995, 14, 1818-1826.

[55] C. Amatore, E.; Carré, A. Jutand, M. A. M'Barki, G. Meyer, Organometallics 1995, 14, 5605-5614.

[56] E.-I. Neghishi, T. Takahashi, K. Akiyoshi, J. Chem. Soc., Chem. Commun. 1986, 1338-1339.

[57] M. T. Reetz, G. Lohmer, R. Schwickardi, Angew. Chem. Int. Ed. 1998, 37, 481-483.

[58] C. Amatore, M. Azzabi, A. Jutand, J. Organomet. Chem. 1989, 363, C41-C45.

[59] C. Amatore, M. Azzabi, A. Jutand, J. Am. Chem. Soc. 1991, 113, 8375-8384.

[60] Review of cross-coupling reactions of aryl chlorides: A. F. Littke, G. C. Fu, Angew. Chem. Int. Ed. 2002, 41, 4176-4211.

[61] The Stille coupling of activated aryl fluorides proceeds with $\left[\mathrm{Pd}\left(\mathrm{PPh}_{3}\right)_{4}\right]$ as the catalyst: Y. M. Kim, S. Yu, J. Am. Chem. Soc. 2003, 125, 1696-1697.

[62] For highlights on the coupling of alkyl electrophiles: (a) D. J. Cárdenas, Angew. Chem. Int. Ed. 1999, 38, 3018-3020; (b) D. J. Cárdenas, Angew. Chem. Int. Ed. 2003, 42, 384-387.

[63] V. V. Grushin, H. Alper, Chem. Rev. 1994, 94, 1047-1062.

[64] (a) Y. Ben-David, M. Portnoy, D. Milstein, J. Am. Chem. Soc. 1989, 111, 8742-8743; (b) Y. Ben-David, M. Portnoy, D. Milstein, J. Chem. Soc., Chem. Commun. 1989, 1816-1817; (c) Y. Ben-David, M. Portnoy, 
M. Gozin, D. Milstein, Organometallics 1992, 11, 1995-1996.

[65] Reviews of palladium-catalyzed amination of aryl electrophiles:

(a) J. F. Hartwig, Angew. Chem. Int. Ed. 1998, 37, 2046-2067; (b) A. R. Muci, S. L. Buchwald, Top. Curr. Chem. 2002, 219, 131-209; (c) D. Prim, J.-M. Champagne, D. Joseph, B. Andrioletti, Tetrahedron 2002, 58, 2041-2075.

[66] (a) B. C. Hamann, J. F. Hartwig, J. Am. Chem. Soc. 1997, 119, 1238212383; (b) B. C. Hamann, J. F. Hartwig, J. Am. Chem. Soc. 1998 , 120, 7369-7370; (c) B. C. Hamann, J. F. Hartwig, J. Am. Chem. Soc. 1998, 120, 3694-3703; (d) M. Kawatsura, J. F. Hartwig, J. Am. Chem. Soc. 1999, 121, 1473-1478.

[67] D. A. Culkin, J. F. Hartwig, Acc. Chem. Res. 2003, 36, 234-245.

[68] (a) M. Palucki, S. L. Buchwald, J. Am. Chem. Soc. 1997, 119, 1110811109; (b) J. Åhman, J. P. Wolfe, M. V. Troutman, M. Palucki, S. L. Buchwald, J. Am. Chem. Soc. 1998, 120, 1918-1919.

[69] (a) X. Bei, H. W. Turner, W. H. Weinberg, A. S. Guram, J. Org. Chem. 1999, 64, 6797-6803; (b) X. Bei, T. Uno, J. Norris, H. W. Turner, W. H. Weinberg, A. S. Guram, J. L. Petersen, Organometallics 1999, 18, 1840-1853; (c) X. Bei, A. S. Guram, H. W. Turner, W. H. Weinberg, Tetrahedron Lett. 1999, 40, 1237-1241.

[70] (a) T. Yamamoto, O. Saito, A. Yamamoto, J. Am. Chem. Soc. 1981, 103, 5600-5602; (b) T. Yamamoto, M. Akimoto, A. Yamamoto, Chem. Lett. 1983, 1725-1726; (c) T. Yamamoto, M. Akimoto, O. Saito, A. Yamamoto, Organometallics 1986, 5, 1559-1567.

[71] Heck reactions: (a) A. F. Litke, G. C. Fu, J. Org. Chem. 1999, 64, 10-11; (b) A. F. Litke, G. C. Fu, J. Am. Chem. Soc. 2001, 123, 6989-7000.

[72] Amination of aryl bromides and chlorides with $\left[\mathrm{Pd}\left(\mathrm{P}(t \mathrm{Bu})_{3}\right)_{2}\right]$ :

(a) M. Nishiyama, T; Yamamoto, Y. Koie, Tetrahedron Lett. 1998, 39, 617-620; (b) T. Yamamoto, M. Nishi- yama, Y. Koie, Tetrahedron Lett. 1998, 39, 2367-2370; (c) J. F. Hartwig,

M. Kawatsura, S. I. Hauck, K. H. Shaughnessy, L. M. AlcazarRoman, J. Org. Chem. 1999, 64, 55755580; (d) R. Kuwano, M. Utsunomiya, J. F. Hartwig, J. Org. Chem. 2002, 67, 6479-6486; (e) Sonogashira coupling: V. P. W. Böhm, W. A. Herrmann, Eur. J. Org. Chem. 2000, 3679-3681.

[73] Other related phosphines for activation of aryl chlorides: (a) G. Y. Li, J. Org. Chem. 2002, 67, 3643-3650; (b) G. Y. Li, G. Zheng, A. F. Noonan, J. Org. Chem. 2001, 66, 8677-8688; (c) G. Y. Li, Angew. Chem. Int. Ed. 2001, 40, 1513-1516; (d) A. Zapf,

A. Ehrentraut, M. Beller, Angew. Chem. Int. Ed. 2000, 39, $4153-$ 4155; (e) S.-Y. Liu, M. J. Choi, G. C. Fu, Chem. Commun. 2001, 2408-2409;

(f) S. Urgaonkar, M. Nagarajan, J. G. Verkade, Tetrahedron Lett. 2002, 43, 8921-8924.

[74] Trialkylphosphonium salts are practical alternatives to air-sensitive phosphines: M. R. Netherton, G. C. Fu, Org. Lett. 2001, 3, 4295-4298.

[75] (a) S. R. Stauffer, N. A. Beare, J. P. Stambuli, J. F. Hartwig, Am. Chem. Soc. 2001, 123, 4641-4642; (b) N. A. Beare, J. F. Hartwig, J. Org. Chem. 2002, 67, 541-555.

[76] (a) D. W. Old, J. P. Wolfe, S. L. Buchwald, J. Am. Chem. Soc. 1998, 120, 9722-9723; (b) J. P. Wolfe, S. L. Buchwald, Angew. Chem. Int. Ed. 1999, 38, 2413-2416; (c) M. C. Harris,

S. L. Buchwald, J. Org. Chem. 2000, 65, 5327-5333.

[77] N. Kataoka, Q. Shelby, J. P. Stambuli, J. F. Hartwig, J. Org. Chem. 2002, 67, 5553-5566.

[78] X. Bei, T. Crevier, A. S. Guram, B. Jandeleit, T. S. Powers, H. W. Turner, T. Uno, W. H. Weinberg, Tetrahedron Lett. 1999, 40, 3855-3858.

[79] J. P. Wolfe, R. A. Singer, B. H. Yang, S. L. Buchwald, J. Am. Chem. Soc. 1999, 121, 9550-9561.

[80] M. Gómez Andreu, A. Zapf, M. Beller, Chem. Commun. 2000, 2475-2476.

[81] Suzuki coupling with $\operatorname{Pd}(0)$ coordinated to 15 -membered triolefinic 
macrocycles: (a) J. Cortés, M. MorenoMañas, R. Pleixats, Eur. J. Org. Chem. 2000, 239-243; (b) A. Llobet, E. Masllorens, M. Moreno-Mañas, A. Pla-Quintana, M. Rodríguez, A. Roglans, Tetrahedron Lett. 2002, 43, 1425-1428.

[82] M. R. Netherton, M. R. C. Dai, K. Neuschütz, G. C. Fu, J. Am. Chem. Soc. 2001, 123, 10099-10100.

[83] J. H. Kirchhoff, C. Dai, G. C. Fu, Angew. Chem. Int. Ed. 2002, 41, 1945-1947.

[84] A. C. Frisch, N. Shaikh, A. Zapf, M. Beller, Angew. Chem. Int. Ed. 2002, 41, 4056-4059.

[85] M. R. Netherton, G. C. Fu, Angew. Chem. Int. Ed. 2002, 41, 39103912.

[86] J. H. Kirchhoff, M. R. Netherton, I. D. Hills, G. C. Fu, J. Am. Chem. Soc. 2002, 124, 13662-13663.

[87] K. Menzel, G. C. Fu, J. Am. Chem. Soc. 2003, 125, 3718-3719.

[88] L. M. Alcazar-Roman, J. F. Hartwig, J. Am. Chem. Soc. 2001, 123, 12905-12906.

[89] A. F. Litke, G. C. Fu, J. Am. Chem. Soc. 2001, 123, 6989-7000.

[90] A. F. Litke, G. C. Fu, J. Am. Chem. Soc. 2000, 122, 4020-4028.

[91] (a) A. F. Littke, G. C. Fu, Angew. Chem. Int. Ed. 1999, 38, 2411-2413; (b) A. F. Littke, G. C. Fu, Angew. Chem. Int. Ed. 1998, 37, 3387-3388.

[92] G. A. Grasa, M. S. Viciu, J. Huang, S. P. Nolan, J. Org. Chem. 2001, 66, 7729-7737.

[93] A. F. Littke, L. Schwarz, G. C. Fu, J. Am. Chem. Soc. 2002, 124, 6344-6348.

[94] F. Paul, J. Patt, J. F. Hartwig, Organometallics 1995, 14, 3030-3039.

[95] F. Paul, J. Patt, J. F. Hartwig, J. Am. Chem. Soc. 1994, 116, 5969-5970.

[96] J. F. Hartwig, F. Paul, J. Am. Chem. Soc. 1995, 117, 5373-5374.

[97] A. H. Roy, J. F. Hartwig, J. Am. Chem. Soc. 2001, 123, 1232-1233.

[98] E. Galardon, S. Ramdeehul, J. M. Brown, A. Cowley, K. K. Hii, A. Jutand, Angew. Chem. Int. Ed. 2002, 41, 1760-1763.
[99] J. P. Stambuli, M. Bühl, J. F. Hartwig, J. Am. Chem. Soc. 2002, 124, 9346-9347.

[100] W. Baratta, S. Stoccoro, A. Doppiu, E. Hertweck, A. Zucca, P. Rigo, Angew. Chem. Int. Ed. 2003, 42, 105-108.

[101] J. P. Stambuli, R. Kuwano, J. F. Hartwig, Angew. Chem. Int. Ed. 2002, 41, 4746-4748.

[102] Y. Mori, M. Seki, J. Org. Chem. 2003, 68, 1571-1574.

[103] B. M. Choudary, S Madhi, N. S. Chowdari, M. L. Kantam, B. Sreedhar, J. Am. Chem. Soc. 2002, 124, 14127-14136.

[104] I. P. Beletskaya, J. Organomet. Chem. 1982, 250, 551-564.

[105] For a recent leading reference on the mechanism of the Heck reaction with palladium metal: J. Le Bars, U. Specht, J. S. Bradley, D. G. Blackmond, Langmuir 1999, 15, 7621-7625.

[106] Q.-S. Hu, Y. Lu, Z.-Y. Tang, H.-B. Yu, J. Am. Chem. Soc. 2003, 125 , 2856-2857.

[107] D. K. Morita, J. K. Stille, J. R. Norton, J. Am. Chem. Soc. 1995, 117, 8576-8581.

[108] K.-C. Kong, C.-H. Cheng, J. Am. Chem. Soc. 1991, 113, 6313-6315.

[109] B. E. Segesltein, T. W. Butler, B. L. Chenard, J. Org. Chem. 1995, 60, 12-13.

[110] F. E. Goodson, T. I. Wallow, B. M. Novak, J. Am. Chem. Soc. 1997, 119, 12441-12453.

[111] Review: W. A. Herrmann, Angew. Chem. Int. Ed. 2002, 41, 1290-1309.

[112] (a) D. S. McGuinness, M. J. Green, K. J. Cavell, B. W. Skelton, A. H. White, J. Organomet. Chem. 1998, 565, 165-178; (b) D. S. McGuinness, K. J. Cavell, B. W. Skelton, A. H. White, Organometallics 1999, 18, 1596-1605.

[113] (a) S. Caddick, F. G. N. Cloke, P. B. Hitchcock, J. Leonard, A. K. de K. Lewis, D. McKerrecher, L. R. Titcomb, Organometallics 2002, 21, 4318-4319; (b) W. J. Marshall, V. V. Grushin, Organometallics 2003, 22, 1591-1593. 
[114] J. Dupont, M. Pfeffer, J. Spencer, Eur. J. Inorg. Chem. 2001, 1917-1927.

[115] (a) R. B. Bedford, C. S. J. Cazin, Chem. Commun. 2001, 1540-1541; (b) R. B. Bedford, C. S. J. Cazin, S. L. Hazelwood, Angew. Chem. Int. Ed. 2002, 41, 4120-4122; (c) R. B. Bedford, C. S. J. Cazin, S. J. Coles, T. Gelbrich, P. N. Horton, M. B. Hursthouse, M. E. Light, Organometallics 2003, 22, 987-999.

[116] A. Schnyder, A. F. Indolese, M. Studer, H.-U. Blaser, Angew. Chem. Int. Ed. 2002, 41, 3668-3671.

[117] (a) D. A. Alonso, C. Nájera, M. C. Pacheco, Org. Lett. 2000, 2, 1823-1826; (b) D. A. Alonso, C. Nájera, M. C. Pacheco, J. Org. Chem. 2002, 67, 5588-5594; (c) D. A. Alonso, C. Nájera, M. C. Pacheco, Adv. Synth. Catal. 2002, 344, 172-183;

(d) L. Botella, C. Nájera, Angew. Chem. Int. Ed. 2002, 41, 179-181.

[118] (a) M. Beller, H. Fischer, W. A. Herrmann, K. Öfele, C. Brossmer, Angew. Chem., Int. Ed. Engl. 1995, 34, 1848-1849; (b) S. Gibson, D. F. Foster, G. R. Eastham, R. P. Tooze, D. J. ColeHamilton, Chem. Commun. 2001, 779-780; (c) D. A. Albisson, R. B. Bedford, S. E. Lawrence, P. N. Scully, Chem. Commun. 1998, 2095-2096; (d) R. B. Bedford, S. L. Welch, Chem. Commun. 2001, 129-130; (e) R. B. Bedford, S. M. Draper, P. N. Scully, S. L. Welch, New J. Chem. 2000, 745-746;

(f) D. Zim, A. S. Gruber, G. Ebeling, J. Dupont, A. L. Monteiro, Org. Lett. 2000, 2, 2881-2884; (g) H. Weissman, D. Milstein, Chem. Commun. 1999, 1901-1902.

[119] I. P. Beletskaya, A. N. Kashin, N. B. Karlstedt, A. V. Mitin, A. V. Cheprakov, G. M. Kazankov, J. Organomet. Chem. 2001, 622, 89-96.

[120] M. P. Muñoz, B. Martín-Matute, C. Fernández-Rivas, D. J. Cárdenas, A. M. Echavarren, Adv. Synt. Catal. 2001, 343, 338-342.

[121] C. S. Consorti, M. L. Zanini, S. Leal, G. Ebeling, J. Dupont, Org. Lett. 2003, 5, 983-986.
[122] C. Rocaboy, J. A. Gladysz, New J. Chem. 2003, 27, 39-49.

[123] (a) T. Rosner, J. Le Bars, A. Pfaltz, D. G. Blackmond, J. Am. Chem. Soc. 2001, 123, 1848-1855; (b) T. Rosner, A. Pfaltz, D. G. Blackmond, J. Am. Chem. Soc. 2001, 123, 4621-4622.

[124] (a) A. J. Canty, Acc. Chem. Res. 1992, 25, 83-90; (b) A. J. Canty, Platinum Metals Rev. 1993, 37, 2-7.

[125] M. Catellani, F. Frignani, Ar. Rangoni, Angew. Chem. Int. Ed. 1997, 36, 119-122.

[126] The X-ray structure of a Pd(IV) complex formed by oxidative addition of PhI to a Pd(II) complex had been published. This structure included several improbable features:

(a) J. M. Brunel, M.-H. Hirlemann, A. Heumann, G. Buono, Chem. Commun. 2000, 1869-1870;

(b) J. M. Brunel, M.-H. Hirlemann, A. Heumann, G. Buono,

Chem. Commun. 2001, 1896 and 2298. This communication has been retracted (16 May 2002).

[127] For theoretical work on a hypothetical mechanism for the Heck reaction based on $\mathrm{Pd}(\mathrm{II}) / \mathrm{Pd}(\mathrm{IV})$ : A. Sundermann, O. Uzan, J. M. L. Martin, Chem. Eur. J. 2001, 7, 1703-1711.

[128] (a) J. Terao, H. Watanabe, A. Ikumi, H. Kuniyasu, N. Kambe, J. Am. Chem. Soc. 2002, 124, 4222-4223; (b) J. Terao, A. Ikumi, H. Kuniyasu, N. Kambe, J. Am. Chem. Soc. 2003, 125, 5646-5647.

[129] (a) E. Shirakawa, H. Yoshida, T. Hiyama, Tetrahedron Lett. 1997, 38, 5177-5180; (b) E. Shirakawa, T. Hiyama, J. Organomet. Chem. 1999, 576, 169-178; (c) E. Shirakawa, H. Yoshida, T. Kurahashi, Y. Nakao, T. Hiyama, J. Am. Chem. Soc. 1998, 120, 2975-2976; (d) H. Yoshida, E. Shirakawa, T. Kurahashi, Y. Nakao, T. Hiyama, Organometallics 2000, 19, 5671-5678; (e) E. Shirakawa, Y. Murota, Y. Nakao, T. Hiyama, Synlett 1997, 1143-1144; (f) E. Shirakawa, Y. Nakao, Y. Murota, T. Hiyama, J. Organomet. Chem. 2003, 670, 132-136. 
[130] Density functional study on the oxidative addition of alkynyl stannanes to $\left[\operatorname{Pd}(\mathrm{L})_{2}\right]$ : T. Matsubara, K. Hirao, Organometallics 2002, 21, 4482-4489.

[131] (a) E. Shirakawa, K. Yamasaki, H. Yoshida, T. Hiyama, J. Am. Chem. Soc. 1999, 121, 10221-10222; (b) E. Shirakawa, H. Yoshida, Y. Nakao, T. Hiyama, Org. Lett. 2000, 2, 2209-2211.

[132] (a) N. A. Bumagin, A. N. Kasatkin, I. P. Beletskaya, Izv. Akad. Nauk. SSSR, Ser. Khim. (Engl. Transl.) 1984, 588-594; (b) O. A. Wallner, K. J. Szabó, Org. Lett. 2002, 4, 1563-1566.

[133] M. Shi, K. M. Nicholas, J. Am. Chem. Soc. 1997, 119, 5057-5058.

[134] B. Martín-Matute, E. Buñuel, D. J. Cárdenas, M. Méndez, C. NietoOberhuber, A. M. Echavarren, Unpublished results, UAM, 2003.

[135] (a) D. J. Cárdenas, C. Mateo, A. M. Echavarren, Angew. Chem. Int. Ed. 1994, 33, 2445-2447; (b) C. Mateo, D. J. Cárdenas, C. Fernández-Rivas, A. M. Echavarren, Chem. Eur. J. 1996, 2, 1596-1606.

[136] C. Mateo, C. Fernández-Rivas, A. M. Echavarren, D. J. Cárdenas, Organometallics 1997, 16, 1997-1999.

[137] Platinum catalysts in Suzuki-type reactions: R. B. Bedford, S. L. Hazelwood, D. A. Albisson, Organometallics 2002, 21, 2599-2600.

[138] W. D. Cotter, L. Barbour, K. L. McNamara, R. Hechter, R J. Lachicotte, J. Am. Chem. Soc. 1998, 120, 11016-11017.

[139] A. Ricci, A. Angelucci, M. Bassetti, C. Lo Sterzo, J. Am. Chem. Soc. 2002, 124, 1060-1071.

[140] (a) L. Spadoni, C. Lo Sterzo, R. Crescenzi, G. Frachey, Organometallics 1995, 14, 3149-3151; (b) P. Cianfriglia, V. Narducci, C. Lo Sterzo, E. Viola, G. Bocelli, T. A. Kodenkandath, Organometallics 1996, 15, 5220-5230; (c) S. Tollis, V. Narducci, P. Cianfriglia, C. Lo Sterzo, E. Viola, Organometallics 1998, 17, 2388-2390; (d) F. Angelucci, A. Ricci, C. Lo Sterzo, D. Masi, C. Bianchini, G. Bocelli Organometallics 2002, 21, 3001-3008.
[141] J. Louie, J. F. Hartwig, J. Am. Chem. Soc. 1995, 117, 11598-11599.

[142] V. Farina, B. Krishnan, J. Am. Chem. Soc. 1991, 113, 9585-9595.

[143] V. Farina, S. R. Baker, D. A. Benigni, C. Sapino, Tetrahedron Lett. 1988, 29, 5739-5742.

[144] Review on 2-furyl phosphanes: N. G. Andersen, B. A. Keay, Chem. Rev. 2001, 101, 997-1030.

[145] V. Farina, B. Krishnan, D. R. Marshall, G. P. Roth, J. Org. Chem. 1993, 58, 5434-5444.

[146] Cross, R. J. Adv. Inorg. Chem. 1989, 34, 219-292.

[147] A. L. Casado, P. Espinet, J. Am. Chem. Soc. 1998, 120, 8978-8985.

[148] J. A. Casares, P. Espinet, G. Salas, Chem. Eur. J. 2002, 8, 4843-4853.

[149] C. Amatore, A. A. Bahsoun, A. Jutand, G. Meyer, A. Ndedi Ntepe, L. Ricard, J. Am. Chem. Soc. 2003, 125, 4212-4222.

[150] A. L. Casado, P. Espinet, A. M. Gallego, J. Am. Chem. Soc. 2000, 122, 11771-11782.

[151] A. L. Casado, P. Espinet, A. M. Gallego, J. M. Martínez-Ilarduya, Chem. Commun. 2001, 339-340.

[152] (a) A. I. Roshchin, N. A. Bumagin, I. P. Beletskaya, Tetrahedron Lett. 1995, 36, 125-128; (b) R. Rai, K. B. Aubrecht, D. B. Collum, Tetrahedron Lett. 1995, 36, 3111-3114.

[153] (a) J. M. Brown, M. Pearson, J. T. B. H. Jastrzebski, G. van Koten, J. Chem. Soc., Chem. Commun. 1992, 1440-1441; (b) E. Fouquet, M. Pereyre, A. L. Rodriguez, J. Org. Chem. 1997, 62, 5242-5243.

[154] E. Vedejs, A. R. Haigt, W. O. Moss, J. Am. Chem. Soc. 1992, 114, 6556-6558.

[155] (a) M. S. Jensen, C. Yang, Y. Hsiao, N. Rivera, K. M. Wells, J. Y. L. Chung, N. Yasuda, D. L. Hughes, P. J. Reider, Org. Lett. 2000, 2, 1081-1084; (b) H. L. Sebahar, K. Yoshida, L. S. Hegedus, J. Org. Chem. 2002, 67, 3788-3795; (c) Intramolecular coordination by an amine also facilitates the transmetallation of less reactive organobismuth compounds with aryl bromides: S. Shimada, O. Yamazaki, 
T. Tanaka, M. L. N. Rao, Y. Suzuki, M. Tanaka, Angew. Chem. Int. Ed. 2003, 42, 1845-1848.

[156] K. Itami, T. Kamei, J. Yoshida, J. Am. Chem. Soc. 2001, 123, 8773-8779.

[157] (a) L. S. Liebeskind, R. W. Fengl, J. Org. Chem. 1990, 55, 5359-5364; (b) L. S. Liebeskind, S. W. Riesinger, J. Org. Chem. 1993, 58, 408-413.

[158] E. Gómez-Bengoa, A. M. Echavarren, J. Org. Chem. 1991, 56, 3497-3501.

[159] V. Farina, S. Kapadia, B. Krishnan, C. Wang, L. S. Liebeskind, J. Org. Chem. 1994, 59, 5905-5911.

[160] A. L. Casado, P. Espinet, Organometallics 2003, 22, 1305-1309.

[161] E. Piers, T. Wong, J. Org. Chem. 1993, 58, 3609-3610.

[162] T. Takeda, K. I. Matsunaga, Y. Kabasawa, T. Fukiwara, Chem. Lett. 1995, 771-772.

[163] J. R. Falck, R. K. Bahtt, J. Ye, J. Am. Chem. Soc. 1995, 117, 5973-5982.

[164] R. J. Linderman, J. M. Siedlecki, J. Org. Chem. 1996, 61, 6492-6493.

[165] (a) G. D. Allred, L. S. Liebeskind, J. Am. Chem. Soc. 1996, 118, 2748-2749; (b) S. Zhang, D. Zhang, L. S. Liebeskind, J. Org. Chem. 1997, 62, 2312-2313.

[166] Coupling catalyzed by $\mathrm{Cu}(\mathrm{I})$ or $\mathrm{Mn}(\mathrm{II})$ : S.-K. Kang, J.-S. Kim, S.-C. Choi, J. Org. Chem. 1997, 62, 4208-4209.

[167] B. M. Savall, N. Blanchard, W. R. Roush, Org. Lett. 2003, 5, 377-379.

[168] F.-A. Alphonse, F. Suzenet, A. Keromnes, B. Lebret, G. Guillaumet, Org. Lett. 2003, 5, 803-805.

[169] M. Egi, L. S. Liebeskind, Org. Lett. 2003, 5, 801-802.

[170] K. Matos, J. A. Soderquist, J. Org. Chem. 1998, 63, 461-470.

[171] B. H. Ridgway, K. A. Woerpel, J. Org. Chem. 1998, 63, 458-460.

[172] A. O. Aliprantis, J. W. Canary, J. Am. Chem. Soc. 1994, 116, 6985-6986.

[173] D. Zim, V. R. Lando, J. Dupont, A. L. Monteiro, Org. Lett. 2001, 3, 3049-3051.

[174] M. Moreno-Mañas, M. Pérez, R. Pleixats, J. Org. Chem. 1996, 61, 2346-2351.
[175] (a) K. Hirabayashi, J. Kawashima, Y. Nishihara, A. Mori, T. Hiyama, Org. Lett. 1999, 1, 299-302; (b) S. E. Denmark, R. F. Sweis, J. Am. Chem. Soc. 2001, 123, 6439-6440.

[176] Y. Hatanaka, T. Hiyama, J. Org. Chem. 1989, 54, 268-270.

[177] Y. Hatanaka, K. Goda, T. Hiyama, J. Organomet. Chem. 1994, 465, 97-100.

[178] (a) G. Stork, R. C. A. Isaacs, J. Am. Chem. Soc. 1990, 112, 7399-7400; (b) C. A. Busacca, J. Swestock, R. E. Johnson, T. R. Bailey, L. Musza, C. A. Rodger, J. Org. Chem. 1994, 59, 7553-7556; (c) V. Farina, M. A. Hossain, Tetrahedron Lett. 1996, 37, 6997-7000; (d) T. Choshi, S. Yamada, J. Nobuhiro, Y. Mihara, E. Sugino, S. Hibino, Heterocycles 1998, 48, 11-14; (e) A. Flohr, Tetrahedron Lett. 1998, 39, 5177-5180; (f) A. Flohr, Tetrahedron Lett. 1998, 39, 5177-5180; (g) W. Shen, L. Wang, J. Org. Chem. 1999, 64, 8873-8879.

[179] Y. Hatanaka, T. Hiyama, J. Am. Chem. Soc. 1990, 112, 7793-7794.

[180] Y. Hatanaka, G. Goda, T. Hiyama, Tetrahedron Lett. 1994, 35, 1279-1282.

[181] P. Dierkes, P. W. N. M. van Leeuwen, J. Chem. Soc., Dalton Trans. 1999, 1519-1530.

[182] (a) J. M. Brown, P. J. Guiry, Inorg. Chim. Acta 1994, 220, 249-259;

(b) M. J. Calhorda, J. M. Brown, N. A. Cooley, Organometallics 1991, 10, 1431-1438.

[183] The same effect has been observed in other reductive eliminations:

(a) G. Mann, D. Baranano, J. F. Hartwig, A. L. Rheingold, I. A. Guzei, J. Am. Chem. Soc. 1998, 120, 9205-9219; (b) J. E. Marcone, K. G. Moloy, J. Am. Chem. Soc. 1998, 120, 8527-8528.

[184] T. Hayashi, M. Konishi, Y. Kobori, M. Kumada, T. Higuchi, K. Hirotsu, J. Am. Chem. Soc. 1984, 106, 158-163.

[185] M. Kranenburg, P. C. J. Kamer, P. W. N. M. van Leeuwen, Eur. J. Inorg. Chem. 1998, 155-157. 
[186] (a) A. Goliaszewski, J. Schwartz, Organometallics, 1985, 4, 417-419; (b) A. Goliaszewski, J. Schwartz, J. Am. Chem. Soc. 1984, 106, 50285030; (c) J. S. Temple, M. Riediker, J. Schwartz, J. Am. Chem. Soc. 1982, 104, 1310-1315; (d) A. Goliaszewski, J. Schwartz, Tetrahedron 1985, 41, 5779-5789.

[187] R. Bertani, A. Berton, G. Carturan, R. Campostrini, J. Organomet. Chem. 1988, 349, 263-268.

[188] (a) S. Numata, H. Kurosawa, J. Organomet. Chem. 1977, 131, 301308; (b) H. Kurosawa, K. Shiba, K. Hirako, K. Kakiuchi, I. Ikeda, J. Chem. Soc., Chem. Commun. 1994, 1099-1100; (c) H. Kurosawa,

M. Emoto, Y. Kawasaki, J. Organomet. Chem. 1988, 346, 137-146;

(d) H. Kurosawa, M. Emoto,

H. Ohnishi, K. Miki, N. Kasai, K. Tatsumi, A. Nakamura, J. Am. Chem. Soc. 1987, 109, 6333-6340.

[189] A. C. Albéniz, P. Espinet, B. MartínezRuiz, Chem. Eur. J. 2001, 7, 2481-2489.

[190] For a review on the palladiumcatalyzed allyl/allyl coupling, see: M. Méndez, A. M. Echavarren, Eur. J. Org. Chem. 2002, 15-28.

[191] H. Nakamura, K. Aoyagi, J.-G. Shim, Y. Yamamoto, J. Am. Chem. Soc. 2001, 123, 372-377.

[192] K. J. Szabó, Chem. Eur. J. 2000, 4413-4421.

[193] B. Henc, P. W. Jolly, R. Salz, S. Stobbe, G. Wilke, R. Benn, R. Mynott, K. Seevogel, R. Goddard, C. Kruger, J. Organomet. Chem. 1980, 191, 449-475.

[194] O. Kuhn, H. Mayr, Angew. Chem. Int. Ed. 1999, 38, 343-346.

[195] J. Krause, R. Goddard, R. Mynott, K.-R. Pörschke, Organometallics 2001, 20, 1992-1999.

[196] P. W. Jolly, Angew. Chem. Int. Ed. 1985, 24, 283-295.

[197] J. Krause, W. Bonrath, K.-R. Pörschke, Organometallics 1992, 11, 11581167.

[198] M. Méndez, J. M. Cuerva, E. GómezBengoa, D. J. Cárdenas, A. M. Echa- varren, Chem. Eur. J. 2002, 8,

3620-3628.

[199] J. F. Fauvarque, A. Jutand, J. Organomet. Chem. 1979, 177, 273-281.

[200] (a) R. Galarini, A. Musco, R. Pontellini, R. Santi, J. Mol. Catal. 1992, 72, L11-L13; (b) I. Kuwajima, E.-I. Nakamura, Acc. Chem. Res. 1985, 18, 181-187; (c) M. Kosugi, I. Hagiwara, T. Sumiya, T. Migita, Bull. Chem. Soc. Jpn. 1984, 57, 242-246.

[201] M. F. Semmelhack, R. D. Stauffer, T. D. Rogerson, Tetrahedron Lett. 1973, 14, 4519-4522.

[202] M. Miura, M. Nomura, Top. Curr. Chem. 2002, 219, 211-241.

[203] J. L. Rutherford, M. P. Rainka, S. L. Buchwald, J. Am. Chem. Soc. 2002, 124, 15168-15169.

[204] M. S. Viciu, R. A. Kelly, E. D. Stevens, F. Naud, M. Studer, S. P. Nolan, Org. Lett. 2003, 5, 1479-1482.

[205] (a) E. J. Hennessy, S. L. Buchwald, Org. Lett. 2002, 4, 269-272; (b) J. P. Konopelski, J. M. Hottenroth, H. M. Oltra, E. A. Véliz, Z.-C. Yang, Synlett 1996, 609-611; (c) H. C. Hang, E. Drotleff, G. I. Elliott, T. A. Ritsema, J. P. Konopelski, Synthesis 1999, 398-400.

[206] K. Okuro, M. Feruune, M. Miura, M. Nomura, J. Org. Chem. 1993, 58, 7606-7607.

[207] J. F. Hartwig, Angew. Chem. Int. Ed. 1998, 37, 2046-2067.

[208] J. Yin, S. L. Buchwald, J. Am. Chem. Soc. 2002, 124, 6043-6048.

[209] (a) B. A. Anderson, E. C. Bell, F. O. Ginah, N. K. Harn, L. M. Pagh, J. P. Wepsiec, J. Org. Chem. 1998, 63, 8224 -8228; (b) M. Sundermeier, A. Zapf, M. Beller, Angew. Chem. Int. Ed. 2003, 42, 1661-1664. (c) Mechanistic studies indicate that the amine (TMEDA) cocatalyst prevents deactivation of $\operatorname{Pd}(0)$ complexes by cyanide ions: M. Sundermeier, A. Zapf, S. Mutyala, W. Baumann, J. Sans, S. Weiss, M. Beller, Chem. Eur. J. 2003, 9, 1828-1836.

[210] A. S. Guram, S. L. Buchwald, J. Am. Chem. Soc. 1994, 116, 7901-7902. 
[211] R. A. Widenhoefer, S. L. Buchwald, Organometallics 1996, 15, 2755-2763.

[212] M. S. Driver, J. F. Hartwig, Organometallics 1997, 16, 5706-5715.

[213] G. Mann, J. F. Hartwig, J. Am. Chem. Soc. 1996, 118, 13109-13110.

[214] U. K. Singh, E. R. Strieter, D. G. Blackmond, S. L. Buchwald, J. Am. Chem. Soc. 2002, 124, 14104-14114.

[215] L. A. Villanueva, K. A. Abboud, J. M. Boncella, Organometallics 1994, 13, 3921-3931.

[216] M. S. Driver, J. F. Hartwig, J. Am. Chem. Soc. 1997, 119, 8232-8245.

[217] (a) Q. Shelby, N. Kataoka, G. Mann, J. F. Hartwig, J. Am. Chem. Soc. 2000, 122, 10718-10719; (b) G. Mann, C. Incarvito, A. L. Rheingold, J. F. Hartwig, J. Am. Chem. Soc. 1999 , 121, 3224-3225.

[218] (a) A. Aranyos, D. W. Old, A. Koyimori, J. P. Wolfe, J. P. Sadighi, S. L. Buchwald, J. Am. Chem. Soc. 1999, 121, 4369-4378; (b) K. E. Torraca, X. Huang, C. A. Parrish, S. L. Buchwald, J. Am. Chem. Soc. 2001, 123, 10770-10771; (c) S. Kuwabe, K. E. Torraca, S. L. Buchwald, J. Am. Chem. Soc. 2001, 123, 12202-12206.

[219] (a) K. Koo, G. L. Hillhouse, Organometallics 1995, 14, 4421-4423;

(b) P. T. Matsunaga, J. C. Mavropoulos, G. L. Hillhouse, Polyhedron 1995, 14, 175-185.

[220] I. P. Beletskaya, A. L. Bessmertnykh, R. Guilard, Tetrahedron Lett. 1999, 40, 6393-6397.

[221] J. F. Hartwig, J. Am. Chem. Soc. 1996, 118, 7010-7011.

[222] J. Zhao, H. Hesslink, J. F. Hartwig, J. Am. Chem. Soc. 2001, 123, 7220-7227.

[223] G. Mann, J. F. Hartwig, J. Org. Chem. 1997, 62, 5413-5418.

[224] (a) A. Klapars, X. Huang, S. L. Buchwald, J. Am. Chem. Soc. 2002, 124, 7421-7428; (b) J. C. Antilla, A. Kla- pars, S. L. Buchwald, J. Am. Chem. Soc. 2002, 124, 11684-11688; (c) R. K. Gujadhur, C. G. Bates, D. Venkataraman, Org. Lett. 2001, 3, 4315-4317; (d) Yamada, K.; Kubo, T.; Tokuyama, H.; Fukuyama, T. Synlett 2002, 231-234; (e) K. Yamada, T. Kurokawa, H. Tokuyama, T. Fukuyama, J. Am. Chem. Soc. 2003, 125, 6630-6631.

[225] C. G. Bates, R. K. Gujadhur, D. Venkataraman, Org. Lett. 2002, 4, 2803-2806.

[226] (a) D. M. T. Chan, K. L. Monaco, R.-P. Wang, M. P. Winters, Tetrahedron Lett. 1998, 39, 2933-2936;

(b) P. Y. S. Lam, C. G. Clark, S. Saubern, J. Adams, M. P. Winters, D. M. T. Chan, A. Combs, Tetrahedron Lett. 1998, 39, 2941-2944;

(c) D. A. Evans, J. L. Katz, T. R. West, Tetrahedron Lett. 1998, 39, 2937-2940; (d) D. J. Cundy, Forsyth, S. A. Tetrahedron Lett. 1998, 39, 7979-7982;

(e) M. E. Jung, T. I. Lazarova, J. Org. Chem. 1999, 64, 2976-2977;

(f) J. P. Collman, M. Zhong, Org. Lett. 2000, 2, 1233-1236; (g) P. Y. S. Lam, G. Vicent, C. G. Clark, S. Deudon, P. K. Jadhav, Tetrahedron Lett. 2001, 42, 3415-3418; (h) J. C. Antilla, S. L. Buchwald, Org. Lett. 2001, 3, 2077-2079.

[227] A. Klapars, S. L. Buchwald, J. Am. Chem. Soc. 2002, 124, 1484414845.

[228] J. Zanon, A. Klapars, S. L. Buchwald, J. Am. Chem. Soc. 2003, 125 , 2890-2891.

[229] X. Huang, K. W. Anderson, D. Zim, L. Jiang, A. Klapars, S. L. Buchwald, J. Am. Chem. Soc. 2003, 6653-6655.

[230] D. Gelman, L. Jiang, S. L. Buchwald, Org. Lett.2003, 5, 2315-2318.

[230] P. S. Herradura, K. A. Pendola, R. K. Guy, Org. Lett. 2000, 2, 2019-2022.

[231] C. Savarin, J. Srogl, L. S. Liebeskind, Org. Lett. 2002, 4, 4309-4312. 